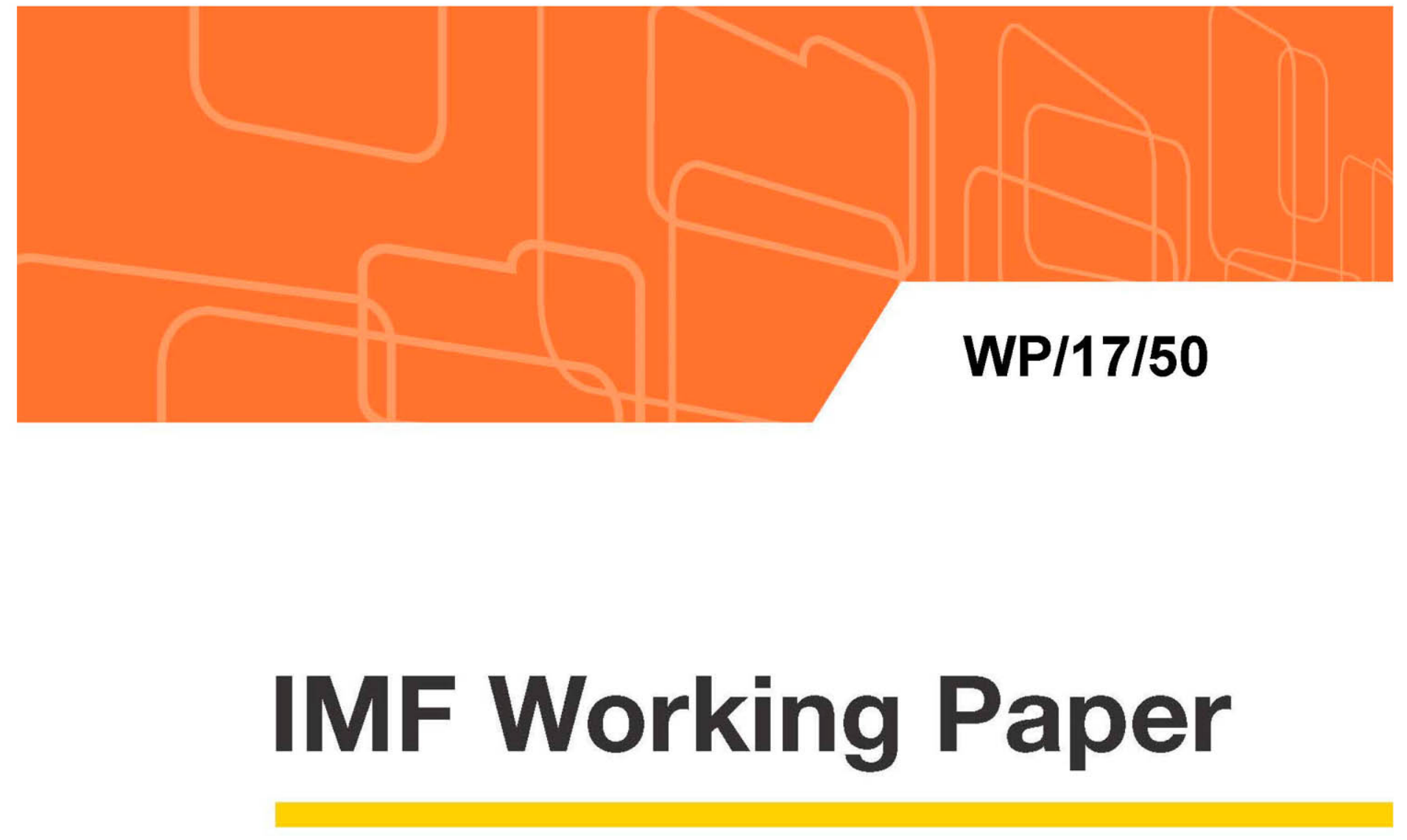

\title{
Spillovers from U.S. Monetary Policy Normalization on Brazil and Mexico's Sovereign Bond Yields
}

by Carlos Góes, Herman Kamil, Phil de Imus, Mercedes Garcia-Escribano, Roberto A. Perrelli, Shaun K. Roache, and Jeremy Zook

IMF Working Papers describe research in progress by the author(s) and are published to elicit comments and to encourage debate. The views expressed in IMF Working Papers are those of the author(s) and do not necessarily represent the views of the IMF, its Executive Board, or IMF management. 


\section{WP/17/50}

\section{IMF Working Paper}

\section{Spillovers from U.S. Monetary Policy Normalization on Brazil and Mexico's Sovereign Bond Yields}

by Carlos Góes, Herman Kamil, Phil de Imus, Mercedes Garcia-Escribano, Roberto A. Perrelli, Shaun K. Roache, and Jeremy Zook

IMF Working Papers describe research in progress by the author(s) and are published to elicit comments and to encourage debate. The views expressed in IMF Working Papers are those of the author(s) and do not necessarily represent the views of the IMF, its Executive Board, or IMF management. 


\title{
IMF Working Paper
}

Western Hemisphere Department

\section{Spillovers from U.S. Monetary Policy Normalization on Brazil and Mexico's Sovereign Bond Yields}

\author{
Prepared by Carlos Góes, Herman Kamil, Phil de Imus, Mercedes Garcia-Escribano, \\ Roberto A. Perrelli, Shaun K. Roache, and Jeremy Zook
}

Authorized for distribution by Alfredo Cuevas and Dora Iakova

March 2017

\begin{abstract}
IMF Working Papers describe research in progress by the author(s) and are published to elicit comments and to encourage debate. The views expressed in IMF Working Papers are those of the author(s) and do not necessarily represent the views of the IMF, its Executive Board, or IMF management.
\end{abstract}

\begin{abstract}
This paper examines the transmission of changes in the U.S. monetary policy to localcurrency sovereign bond yields of Brazil and Mexico. Using vector error-correction models, we find that the U.S. 10-year bond yield was a key driver of long-term yields in these countries, and that Brazilian yields were more sensitive to U.S. shocks than Mexican yields during 2010-13. Remarkably, the propagation of shocks from U.S. long-term yields was amplified by changes in the policy rate in Brazil, but not in Mexico. Our counterfactual analysis suggests that yields in both countries temporarily overshot the values predicted by the model in the aftermath of the Fed's "tapering" announcement in May 2013. This study suggests that emerging markets will need to contend with potential spillovers from shifts in monetary policy expectations in the U.S., which often lead to higher government bond interest rates and bouts of volatility.
\end{abstract}

JEL Classification Numbers: E4, F3, F4

Keywords: QE, tapering, local-currency sovereign bond yields, vector error correction models

Author’s E-Mail Address: cgoes@imf.org; herman.kamil@mef.gub.uy; pdeimus@imf.org; mgarciaescribano@imf.org; rperrelli@imf.org; shaunroache@temasek.com.sg; jeremy.zook@treasury.gov. 


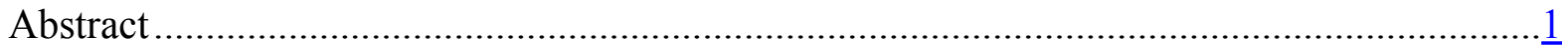

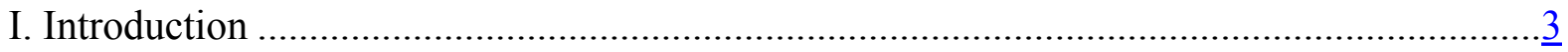

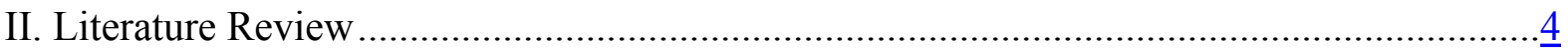

III. Data Description and Model Specification ..................................................................... 6

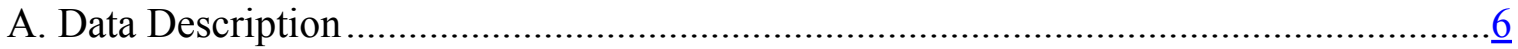

B. Model Specification and Estimation............................................................

IV. Baseline Results ................................................................................................... 11

A. Impulse Responses of Local-Currency 10-Year Sovereign Bond Yields .....................11

B. Observed and Model-Based Yield Estimates around "Tapering Talk".......................14

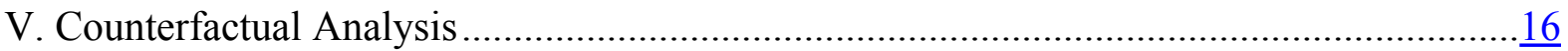

VI. Analysis of Cointegration and Long-Run Equilibria.............................................

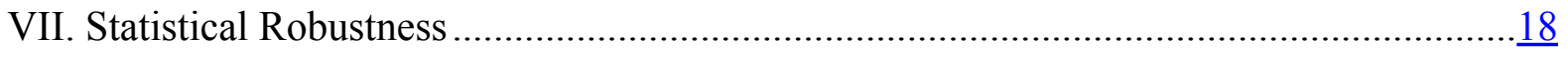

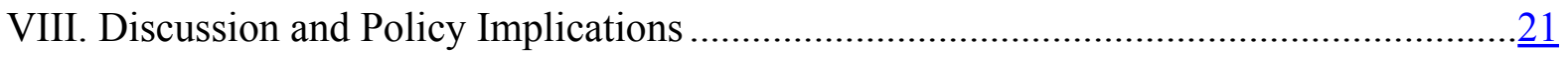

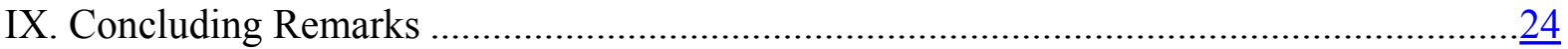

Appendices

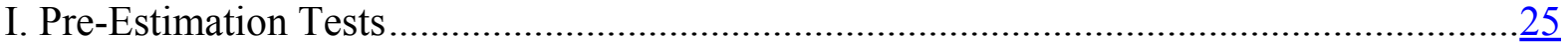

II. Cointegration Test for Near-Integrated Variables....................................................29

III. Time Series Plots .................................................................................................. $\frac{31}{34}$

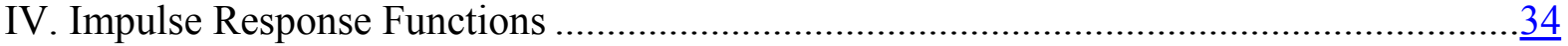

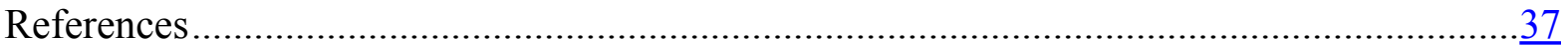




\section{INTRODUCTION ${ }^{1}$}

A key issue at the forefront of policy analysis is how emerging market (EM) countries manage the transition toward U.S. monetary policy normalization. In this paper, we focus on one channel of cross-border transmission: the effects of movements on U.S. long-term treasury yields on local-currency sovereign bond yields, looking at the specific cases of Brazil and Mexico during 2010-13.

Understanding the spillovers of changes in U.S. bond yields to domestic sovereign bond markets is important for several reasons. First, U.S. Treasury yields at long maturities rose significantly after the news of a possible unwinding (tapering) of the U.S.'s quantitative easing (QE) program in May 2013. While the U.S. Federal Reserve's (Fed's) subsequent policy rate increase in December 2015 did not result in another bout of climbing yields, the risk of shifts in Fed expectations persists as it gradually normalizes monetary policy. ${ }^{2}$ Second, in the aftermath of the global financial crisis, EM local-currency bond markets have deepened significantly, with a greater presence of foreign investors that have heightened cross-border linkages. ${ }^{3}$ Finally, increases in sovereign bond yields have implications for government and corporate borrowing costs and access to financing and, therefore, can affect economy-wide financial conditions.

In this paper we study the impact of changes in the 10-year U.S. Treasury yields (UST-10Y) on the Brazilian and Mexican sovereign yields of fixed-rate local-currency bonds of comparable maturity. We use a vector error-correction model to incorporate other domestic and external determinants of local-currency sovereign yields, including sovereign risk, exchange rate volatility, global risk aversion, and the short-term policy rate. The econometric framework takes into account the short-run dynamics among covariates, as well as possible long-run relationships between them. Due to the specific nature of the episode under study, our econometric analysis focuses on the period from August 2010 to October 2013.

We find that changes in the UST-10Y yield have a statistically large and drawn-out impact on the local-currency sovereign bond yields of Brazil and Mexico during the sample period. An increase of 100 basis points in U.S. long-term yields is followed by a rise of about 200 basis points in long-term Brazilian rates after 6 months, and 150 basis points in the case of Mexico over the same time frame. In addition, we find strong evidence in both countries of a long-run equilibrium relationship between the endogenous variables. Even when we relax the assumption that the variables are non-stationary and assume that they are stationary but

\footnotetext{
${ }^{1}$ IMF Working Papers describe research in progress by the author(s) and are published to elicit comments and to encourage debate. The views expressed in IMF Working Papers are those of the author(s) and do not necessarily represent the views of the IMF, its Executive Board, IMF management, or other institutions with which the author(s) are currently affiliated. The authors would like to thank the Brazilian National Treasury Secretariat for useful comments.

${ }^{2}$ U.S. 10-year Treasury yields experienced their post-tapering talk peak at the end of 2013 at about 3 percent.

${ }^{3}$ The IMF's April 2014 Global Financial Stability Report analyzes the evolution of portfolio investment into emerging market economies, including the role of foreigners in EM domestic sovereign bond markets.
} 
highly persistent (i.e. near-integrated) variables, we find evidence of such an equilibrium relationship.

We scrutinize the dynamics of local-currency sovereign bond yields right after the "tapering talk" event in May 2013. Using a counterfactual analysis, we show that actual yields for both countries overshot temporarily the values predicted by the models, with the deviation from the model-based fitted values being larger in the case of Brazil. We further examine whether differences in the impulse responses of these countries' yields can be attributed to indicators of sovereign credit risk. For instance, markets' perception of a country's risk at the onset of the "tapering talk" episode may have increased the sensitivity of the local-currency sovereign bond yields to movements in the 10-year U.S. bond yields.

In addition, we check whether U.S. Treasury yields may have interacted directly with macroeconomic fundamentals, amplifying spillover effects. In this respect, our econometric analysis suggests that policy rates in Brazil and Mexico responded differently to changes in the U.S. long-term yields during the sample period. Brazil's policy rate moved upwards in response to shocks in the U.S. Treasury yields, amplifying the impact of tighter external financial conditions in the domestic economy. In contrast, Mexico's policy rate did not react much to the same shock during that period.

The paper is organized as follows. Section II provides a brief review of the literature. Section III describes the data and the model specification. Section IV presents the baseline results on the response of Brazil and Mexico's local-currency bond yields to the tapering talk. Section V offers a counterfactual analysis of how these bond yields would have responded to the tapering talk if some of the external factors and/or domestic fundamentals were unchanged. Section VI examines the issues of cointegration and long-run equilibria of the variables in the system. Section VII elaborates on the statistical robustness, while Section VIII discusses the policy implications of our results. Section IX concludes the work.

\section{LITERATURE REVIEW}

This paper contributes to the literature on international spillovers of monetary policy in advanced countries to bond markets in emerging economies - in particular, the effect of unconventional monetary policies in the U.S. during the period 2010-13. To achieve this goal, we provide econometric evidence on the drivers of the short- and long-run dynamics of local-currency sovereign bond yields in Brazil and Mexico. We extend the results of the literature on the role of country fundamentals in explaining market reactions to Fed announcements relating to the tapering of its asset purchases. Finally, we contribute with new evidence on the transmission of monetary policy along the local-currency bond yield curve.

Despite the increasing importance of local-currency bond markets for government financing, empirical evidence on the determinants of EM local-currency sovereign bond yields' dynamics is still scant. ${ }^{4}$ Past research has focused on assessing the drivers of the spreads on

\footnotetext{
${ }^{4}$ The bulk of the literature on the determinants of long-term sovereign yields is focused on industrialized economies. For example, Howe and Pigott (1992) provide an overview of the determinants of the long-term
} 
foreign currency sovereign bonds issued externally, specifically analyzing the role of U.S. monetary policy as a driver of EMs bond yields. For instance, Eichengreen and Mody (1998) showed that, in addition to country fundamentals, the external interest rate environment is an important determinant of spreads. Edwards (2010) examines how changes in the term structure of short-term interest rates in advanced economies affected EMs' financial conditions from 2000 through 2008.

A few papers have examined the impact of U.S. unconventional monetary policies on emerging markets asset prices. Fratzscher et al. (2013) investigate the effect of different types of Fed quantitative easing measures (liquidity operations and purchases of mortgagebacked securities and of U.S. Treasury securities) during 2007-10 on portfolio flows and asset prices in the U.S. and globally. Moore et al. (2013) use event study analysis on the impact of the announcements of large scale asset purchases by the Federal Reserve on localcurrency bond yields. Their results suggest a pass-through of approximately 20 percent from U.S. yields to EM yields. Mishra et al. (2014) use an event study framework and daily data for 21 emerging markets. They find that countries with stronger fundamentals, deeper financial markets, and tighter macro-prudential policy stances in the run-up to the tapering announcements experienced smaller currency depreciations and smaller increases in government bond yields, but less differentiation in the behavior of stock prices.

Some studies have focused on the drivers of local-currency bond yields. Miyajima et al. (2012) analyze the importance of domestic and external factors (including the U.S.

10 -year bond yield) in dictating the dynamics of the EM local-currency bond yields. The authors find that a 1-percentage point increase in the U.S. 10-year bond yield lifted the EM local-currency yield by 40-60 basis points in the post-Lehman sample. Jaramillo and Weber (2013) conduct a static panel data analysis with monthly observations for 26 EMs and find that country conditions matter for the transmission of global shocks to long-term domestic bond markets. In particular, they find that weaker fiscal fundamentals and greater nonresident participation in these markets increase the impact of a global risk aversion shock, while the current account deficit matters for the sensitivity to changes in global liquidity. Ebeke and $\mathrm{Lu}$ (2013) present a case study on Poland that models the 5-year local-currency bond yield using an error-correction model with weekly data. They find that the impact of the Fed's balance sheet on domestic yields is inconclusive. Morgan (2011) investigates the impact of the U.S. quantitative easing on local-currency bond yields in the Asian region using event window analysis. The study shows a significant impact only on Indonesian bonds related to a larger presence of foreign investors and relatively open capital account.

Studies tailored to estimate the impact of the U.S. yield on the Brazil and Mexican localcurrency sovereign bond yields are limited. Cortés Espada and Ramos-Francia (2008) analyze the determinants of the term structure of interest rates in Mexico, focusing on the impact of domestic macroeconomic variables. The VAR analysis in Moore et al. (2013)

rates in large advanced economies from the 1970s to the 1990s_-a period marked by sustained increase in real interest rates, in sharp contrast to the environment of the most recent years. More recently, Maltritz (2012) models the sovereign yield spreads in the Eurozone using a Bayesian model averaging, which controls for fiscal variables, external sector variables, and global financing conditions. 
using daily data for the period 2007-11 does not show statistically significant results for Brazil, but does for Mexico. An event study is presented for Mexico and shows that during the first large-scale asset purchase by the Federal Reserve in late-2008 to early 2009, the pass-through to the 10-year bond yield in Mexico was nearly 40 percent. Leon (2014) focuses on foreign participation in bond markets and its effects on Brazilian 5-year sovereign bond yields. She works with monthly data from January 2007 to July 2012, a period that includes the global financial crisis and unconventional monetary policy, but not tapering talk. She finds that the pass-through of U.S. 5-year Treasury yields is near 50 percent in the shortrun dynamics. Matheson (2015) estimates that a 100 basis point shock in U.S. 10-year due to either a monetary shock or a new shock in the U.S. could increase the Brazilian policy rate by around 80 basis points and the long-run rate by around 200 basis points over 6-month period. The latter result is in line with those in this paper. Da Silva et al (2015) discuss contingency plans to mitigate the impact of U.S. interest rate shocks on the Brazilian yield curve, including inter alia the adoption of extraordinary auctions and the issuance of shortduration fixed-rate securities.

\section{Data Description ANd Model Specification}

U.S. Federal Reserve Chairman Bernanke's testimony to the U.S. Congress on May 22, 2013, triggered a sudden change in market expectations on the timing and pace of unwinding the quantitative easing $(\mathrm{QE})$, as well as on the onset of the monetary tightening cycle in the U.S. As a result, the yield on the benchmark 10-year U.S. Treasury bond rose sharply by over 70 basis points to 2.7 percent by end-June that year, then peaking at about 3 percent in early 2014.

Local-currency bond markets in Brazil and Mexico also saw their sovereign yields rise and become more volatile. At their peak, on September 5, 2013, the 10-year local-currency Mexican bond yield had jumped 180 basis points since May 21, 2013, compared with an increase of 108 basis points in the U.S. 10-year rate. Brazilian yields, in turn, had increased by about 213 basis points over the same period (Figure 1). However, the shape of the yield curves had different dynamics in the two countries - while in Mexico it steepened, in Brazil the curve moved in a parallel shift upwards (Figure 2). ${ }^{5}$ There were also signs of disruption in price discovery in the domestic bond market, as reflected in widening bid-ask spreads, higher volatility in yields, and lower average size of transactions (Figure 3).

\section{A. Data Description}

Identifying the underlying drivers - either external or domestic — of the changes in localcurrency sovereign bond yields is key to the present study. Models of long-term interest rates typically decompose the long-term yield into a component that reflects the expected path of short-term interest rates through a security's lifetime, and a component referred to as the risk

\footnotetext{
${ }^{5}$ Part of this behavior is due to the increase in policy rates in Brazil. In this paper, we find evidence that the policy rate in Brazil has been positively influenced by changes in the UST-10Y.
} 
premium. ${ }^{6}$ Extending this model to a globally integrated country requires controls for global interest rates and risk aversion, inflation differential across countries, country-specific risks, exchange-rate risk, and other relevant factors.

With the aim of capturing the most important determinants of local-currency bond yields, in this paper we select variables which are, in our judgement, the best available proxies for the aforementioned constitutive parts of the econometric model. The set of variables is as follows:

- Local 10Y $(l)$ : the nominal yield of a generic fixed-rate, local-currency sovereign bond with 10-year residual maturity, expressed in basis points;

- UST 10Y $(\boldsymbol{u})$ : the nominal yield five-year U.S. Treasury Constant Maturity Rate to maturity of the U.S. Treasury 10-year bond, expressed in basis points, which conceptually includes the world real interest rate, expected U.S. inflation, and a term premium;

- Policy Rate $(\boldsymbol{p})$ : the annualized short-term policy rate set by the central bank for overnight interbank loans, which, combined with other variables, provides measures for term premium inflation differential;

- Inflation Expectations (e): yearly inflation expectations 12-months ahead, either from surveys or implied from the differential between inflation-linked and nominal bonds;

- CDS spread (c): the spread, in basis points, of the 5-year Credit Default Swap USD contract for the emerging country, which measures investors' perception of country risk - i.e. the absolute risk of investing in a given country;

- EMBIG Differential (s): the difference between the EMBIG stripped spread for each country and the EMBIG Global stripped spread, which captures the relative risk of the country in comparison to other emerging markets;

- VIX (v): the Chicago Board Options Exchange Market Volatility Index (VIX) for bidask quotes of options that have the S\&P 500 index as underlying, which is a proxy for global risk aversion; and

- Implied Volatility $(\boldsymbol{i}):$ is the implied volatility of the one-month ahead foreign exchange option, which is meant to capture the short-term currency risk premium.

Most of the data (more specifically, $c, s, p, v$ and $i$ ) are readily available on a daily frequency. Constructing a continuous time series for local-currency bond yields, however, is more complicated. The reason is that bonds have a fixed maturity date, which means that the days until maturity are constantly decreasing over time. As our variable $l$ is the yield for bonds with fixed period until maturity (10 years), we need to track the yields of different bonds over time to construct our continuous time series.

The simplest way to do that is using Bloomberg's generic 10-year bond yield time series for a given country. Bloomberg automatically switches between different underlying securities

\footnotetext{
${ }^{6}$ The risk premium of a bond can be composed in several factors, including a term premium (reflecting investors' willingness to assume duration risk), a credit risk premium, a currency risk, a premium for preferred habitat (driven by the type of investor demand), and the supply of long-term bonds in the market. These, in turn, may reflect, inter alia, variations in market liquidity, regulatory incentives, the need for collateral, and the perceived creditworthiness of the sovereign.
} 
and reports the yield to maturity of the outstanding bond whose length till maturity is the closest to 10 years. If a market is highly liquid, this method works smoothly because most likely there will be an underlying security with approximately 10 years until maturity. Such is the case for the U.S. and Mexico domestic currency 10 -year bond yields. For both countries, we used Bloomberg's generic time series which go back many years.

However, this is not the case for Brazil as the country has a less liquid local-currency sovereign bond market and its term structure is more limited (see Figure 4). For example, during most of 2013 there was not a local-currency non-inflation-linked 10-year sovereign bond outstanding in the Brazilian market. Thus, the empirical approach relies on approximations of the 10-year yields in the absence of specific nodes in the sovereign yield curve. In particular, we use the Reuters' DataStream's proxy for Brazil's 10-year yields. DataStream approximates the 10-year yields by blending 10-year and 9-year sovereign bond yields and constructing a continuous time series. ${ }^{7}$

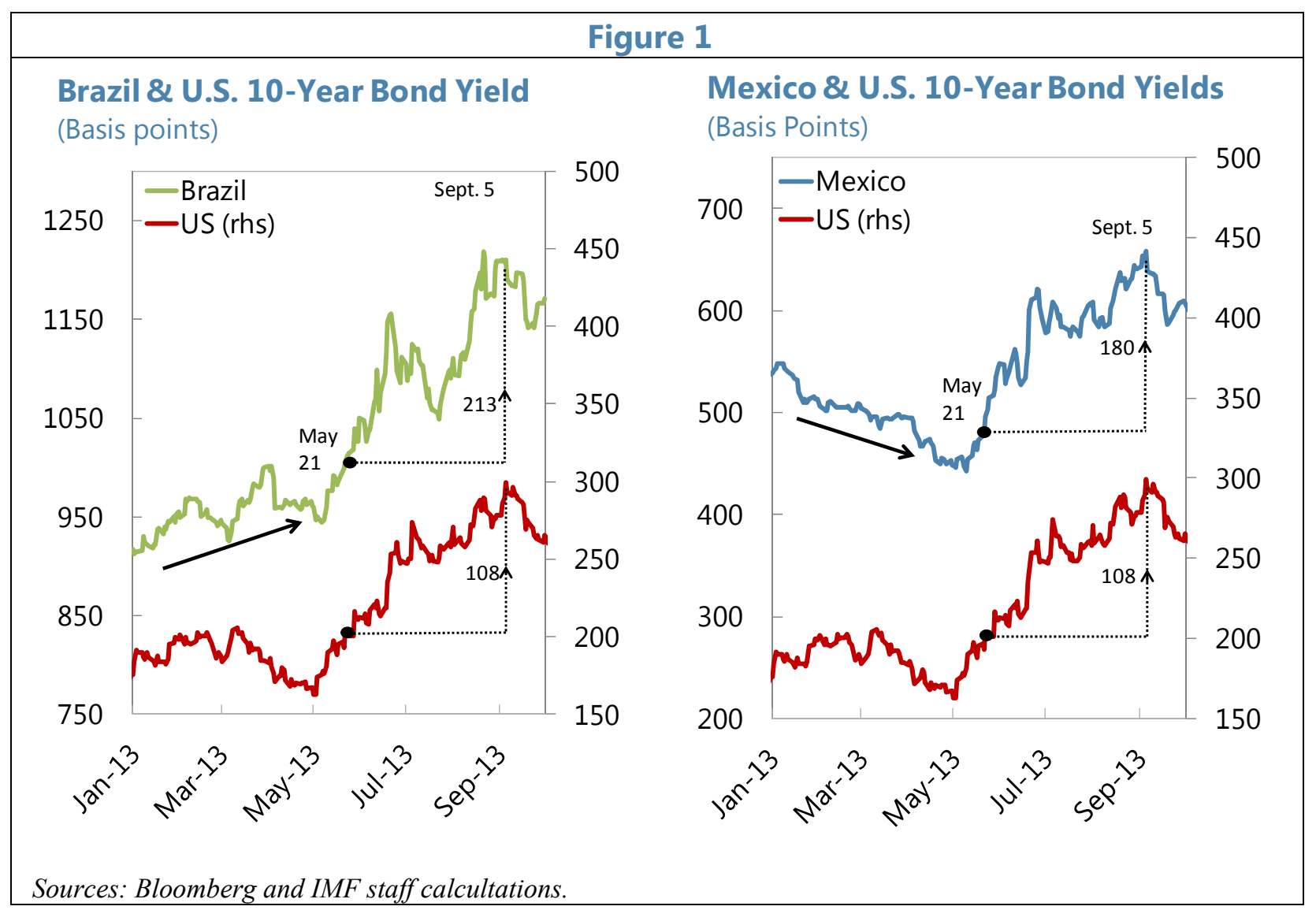

\footnotetext{
${ }^{7}$ Whenever a 10-year bond yield was missing, they have replaced missing values with the 9-year bond yield. As yield curves tend to have a log-function shape, the spread between 10-year and 9-year bonds is not too wide. Additionally, yields in the long-end of the curve are often highly positively correlated. For these reasons, the blend tends be a good approximation and we have decided to use it in our baseline model.
} 


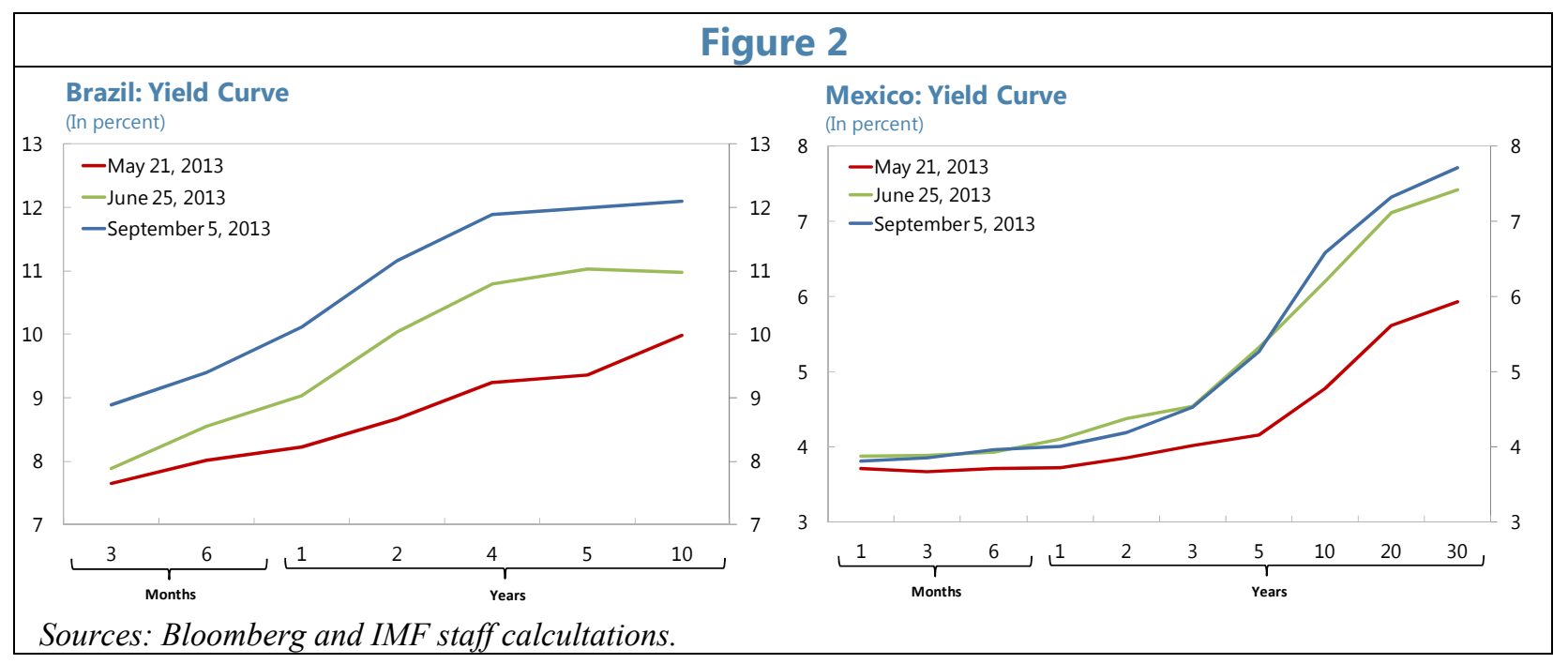

\section{Figure 3}

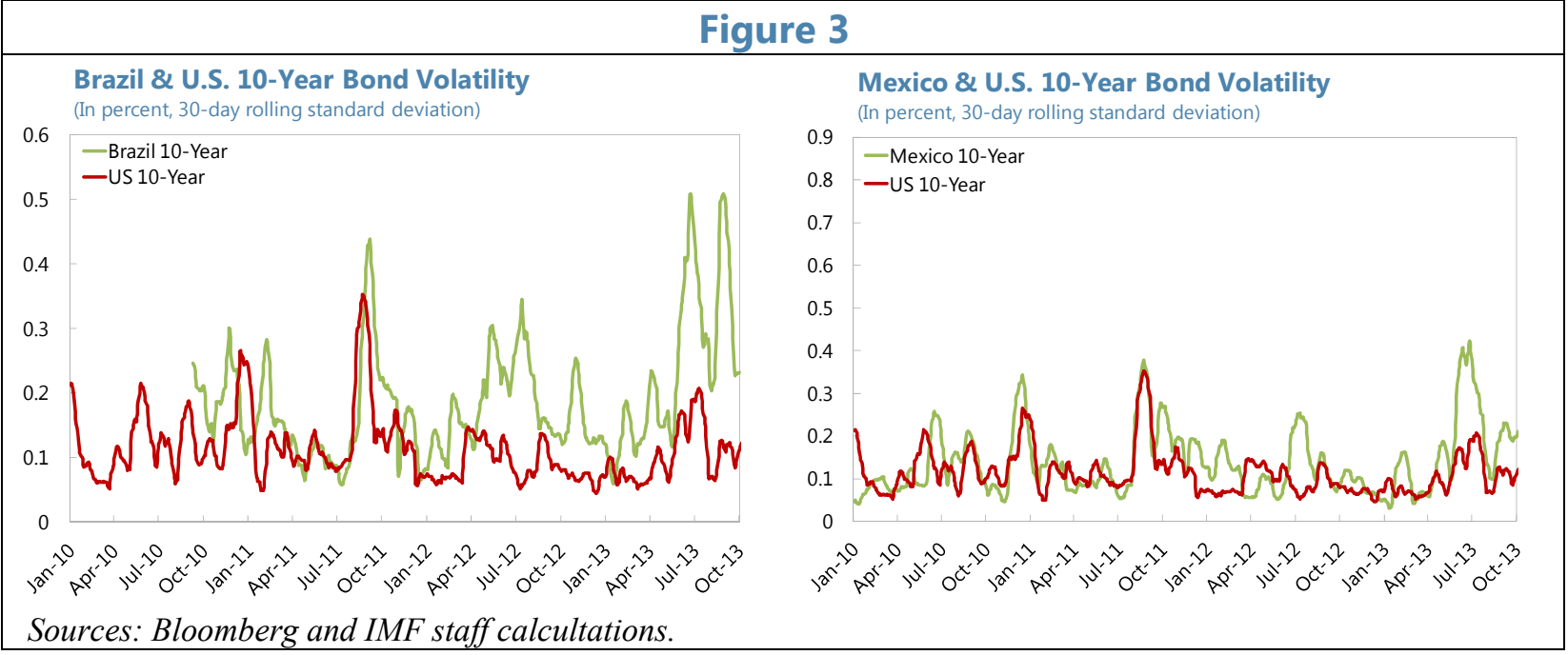

\section{Figure 4}

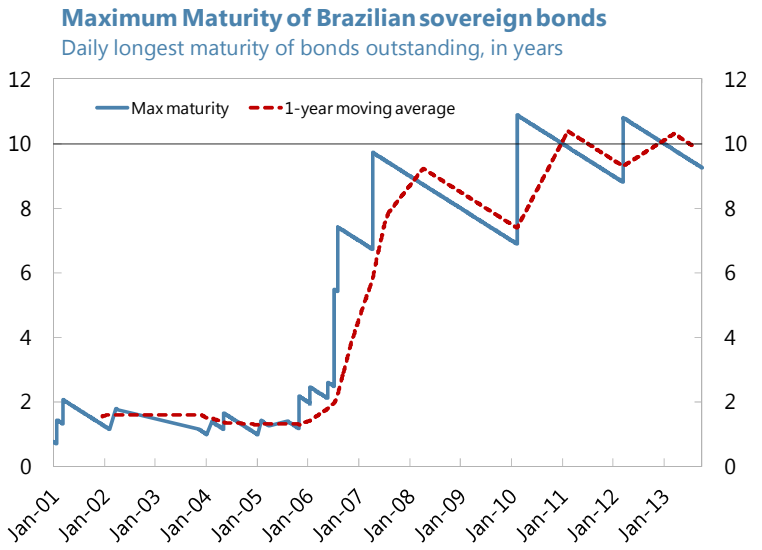

Sources: Bloomberg, with staff estimates.

Note: Excludes days with less than three outstanding bonds (NTNFs or LTNS). 


\section{B. Model Specification and Estimation}

We use a Vector Error Correction model (VECM) to assess the spillovers from the U.S. Treasury yields on the yields of Brazil and Mexico. This approach allows us to derive estimates of short-run dynamics and degree of persistence. It also gives us information on the long-run relationship between local-currency bond yields and fundamental determinants, including on the speed of adjustment to equilibrium. More specifically, we estimated the following VECM:

$$
\Delta X_{t}=\alpha \beta^{\prime} X_{t-1}+\sum_{i=1}^{p} A_{i} \Delta \mathrm{X}_{\mathrm{t}-\mathrm{i}}+C+\epsilon_{t}
$$

where $\mathrm{X}_{\mathrm{t}} \equiv[u, v, c, e, s, p, i, l]^{\prime}$ is a $m$-dimensional vector of endogenous variables; $\alpha \equiv$ $\left[a_{11}, \ldots, a_{1 m}\right]^{\prime}$ is a m-dimensional vector of short-run adjustment coefficients; $\beta^{\prime}$ is a $(m \times l)$ matrix of coefficients for the $l$ cointegrating relationships among the $m$ endogenous variables; $\mathrm{A}$ is a $(m \times \mathrm{m})$ matrix of coefficients determining the short-run dynamics of the endogenous variables; $\mathrm{C}$ is a vector of constants; $\epsilon$ is a vector of error terms. ${ }^{8}$ Model (1) permits to decompose the forecast-error variance of all the endogenous variables, and to trace out the impulse-response functions (IRFs) that show the sensitivity of local-currency sovereign yields (at different maturities) to an innovation in the U.S. 10-year Treasury yield.

Since only the reduced form version of the model (1) can be estimated, we impose additional structure to the error variance-covariance matrix, so that the structural shocks can be identified. We use a standard Cholesky decomposition to make the reduced-form errors orthogonal. Our selected ordering (where the more contemporaneously exogenous variables of the model precede the endogenous ones), has the U.S. 10-year Treasury yield as the "most exogenous" variable and the local-currency 10-year bond yield as the "least exogenous" variable. Other variables are ordered as listed in the vector $\mathrm{X}_{\mathrm{t}}$ of equation (1) above. Global variables precede local variables and country risk variables precede interest rate variables, which is consistent with the standard theory for large financially integrated economies.

Standard errors are estimated with a Monte Carlo simulation involving bootstrapping with 1,000 replications. The algorithm works as follows. We run the baseline model and collect residuals and fitted values for all endogenous variables. We then multiply the reduced-form residuals by the inverse of the Cholesky lower triangular matrix in order to get the structural residuals while preserving the variance-covariance structure of the model. Afterwards, we resample the structural residuals, thereby adding variability to the bootstrapping exercise, and transform them back into reduced-form residuals, now re-sampled. We then create pseudoseries by adding the re-sampled residuals to the fitted values and run a model that mirrors the baseline model (with the same Cholesky ordering), calculate the IRFs with the pseudo-series,

\footnotetext{
${ }^{8}$ While Xt includes $v$ and $i$, which are $\mathrm{I}(0)$, we impose restrictions to the cointegrating relationship such that these variables are not included in the long-run equilibrium but still incorporated in the short-run dynamics.
} 
and store their values. After repeating this procedure 1,000 times, we calculate the standard deviation of the pseudo-IRFs, which represent the standard errors of our baseline IRFs. ${ }^{9}$

\section{BASELINE RESULTS}

In this section we trace the dynamic response of local-currency bond yields of Brazil and Mexico, respectively, to an initial shock of 100 basis points to the U.S. Treasury yield. We do not distinguish whether this unanticipated rise in the 10-year yield reflects a shift in the term premium or a response to changes at the short end of the yield curve, for example due to actual or anticipated policy rate movements. For our purposes this distinction is unnecessary, given the fact that the U.S. policy rate remained anchored near the zero lower bound for considerable time. ${ }^{10}$ Consequently, we interpret the following results as primarily a response to a term premium shock.

\section{A. Impulse Responses of Local-Currency 10-Year Sovereign Bond Yields}

Figure 5 depicts the response of local-currency yields in Brazil and Mexico to an initial shock of 100 basis points (bps) to the U.S. Treasury yield. The entire VECM is affected so the impulse response reflects not only the initial innovation to the Treasury yield but also the interactions among all of the other variables. For example, a rise in Treasury yields could signal a broad tightening in global financial conditions that increases sovereign CDS spreads in emerging markets. In turn, this could imply that both global real interest rates and countryspecific risk components contribute to higher local-currency long-term sovereign yields.

We find that the responses of 10-year yields are statistically significant for both countries but larger in Brazil than in Mexico. The simple "beta"- here defined as the cumulative change after 6 months to an initial 100-basis points shock to the U.S. Treasury yield-is about 200 basis points in Brazil compared to 150 basis points in Mexico (Figure 5). It is not clear that the difference in the impact is statistically significant as the lower bound of the 95 percent confidence interval for Brazil overlaps with the upper confidence interval for Mexico. However, in an alternative exercise, we analyze a shock to the U.S. Treasury yield that is calibrated to reach $100 \mathrm{bps}$ after 6 months. The impulse responses obtained in this case confirm that the sensitivity of sovereign bond yields to the U.S. 10-year Treasury yield was higher in Brazil than in Mexico during the period of analysis.

The IRFs (Figure 6) suggest that differences across countries in the response of localcurrency bond yields to higher U.S. yields can be explained by indirect channels working through domestic variables. In particular, short-term interest rates (policy rates) appear to respond differently to the U.S. shocks. In Brazil, an initial 100bps shock to the U.S. yield leads, on average, to a statistically significant $180 \mathrm{bps}$ rise in the policy rate after 6 months. This change in the policy rate serves to amplify the direct impact of higher long-term yields

\footnotetext{
${ }^{9}$ We thank Robert Blotevogel and Yi Liu for their comments and ideas to improve our bootstrapping algorithm.

${ }^{10}$ Indeed, changes in the U.S. policy rate during the sample period have been minimal, and thus inferences regarding its effects are less reliable. Nevertheless, our robustness tests confirm that including the Fed Funds target rate as a variable in the model did not materially change the qualitative results.
} 
in the U.S. as it lifts the entire yield curve (including through the interest rate expectations channel). In contrast, the same U.S. yield shock has almost no effect on Mexico's policy rate over the same period, thus muting the overall effect.

The forecast-error variance decompositions of the models show that around 45 percent of the variance of both the Brazilian and Mexican 10-year bond yields are explained by innovations in the U.S. yields (Figure 7). In the case of Brazil, innovations in the CDS spread and inflation expectations explain more of the variance compared to Mexico. While for Mexico, the VIX, the country's EMBIG spread relative to peers, and the policy rate explain a higher fraction of the variance than for Brazil.

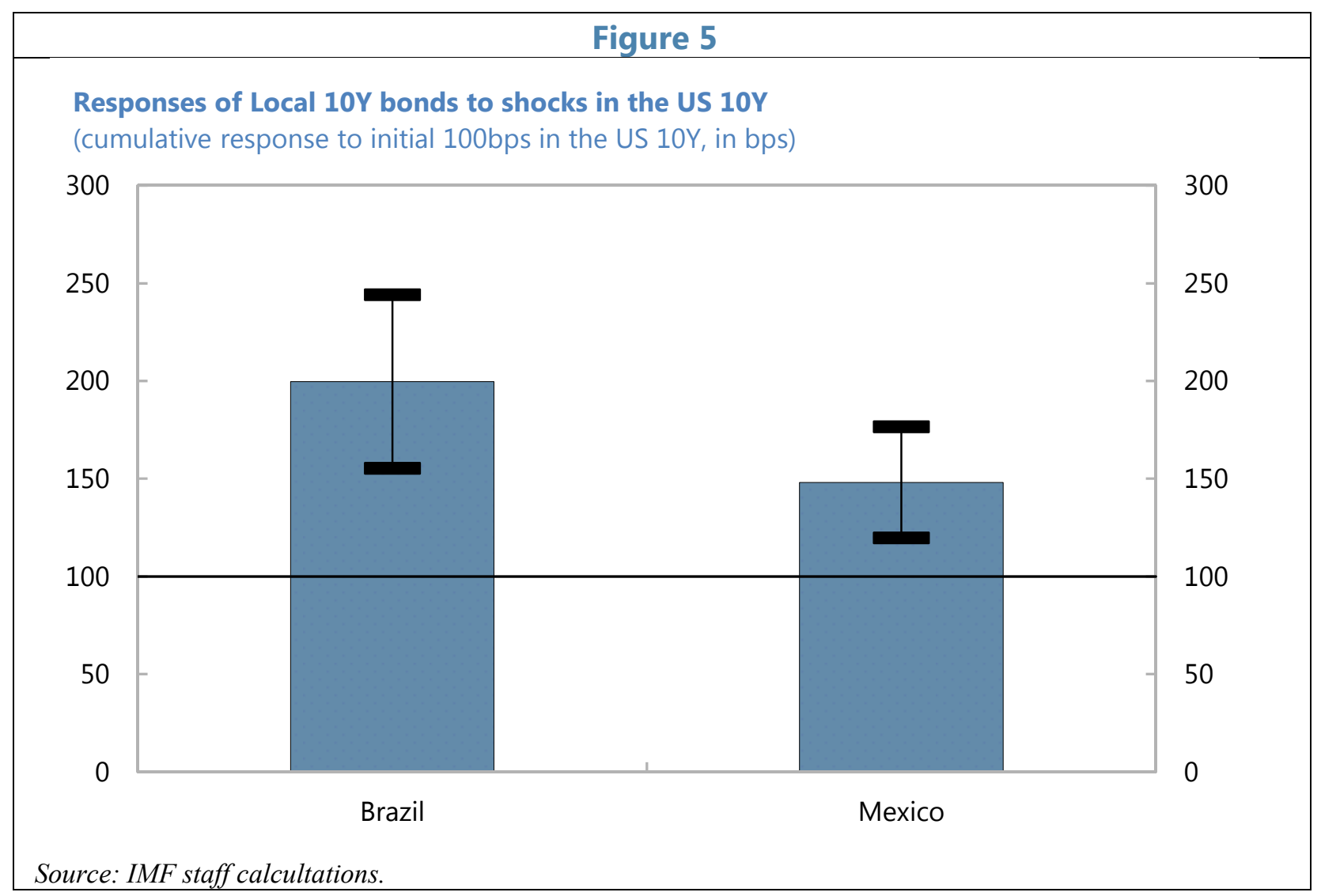




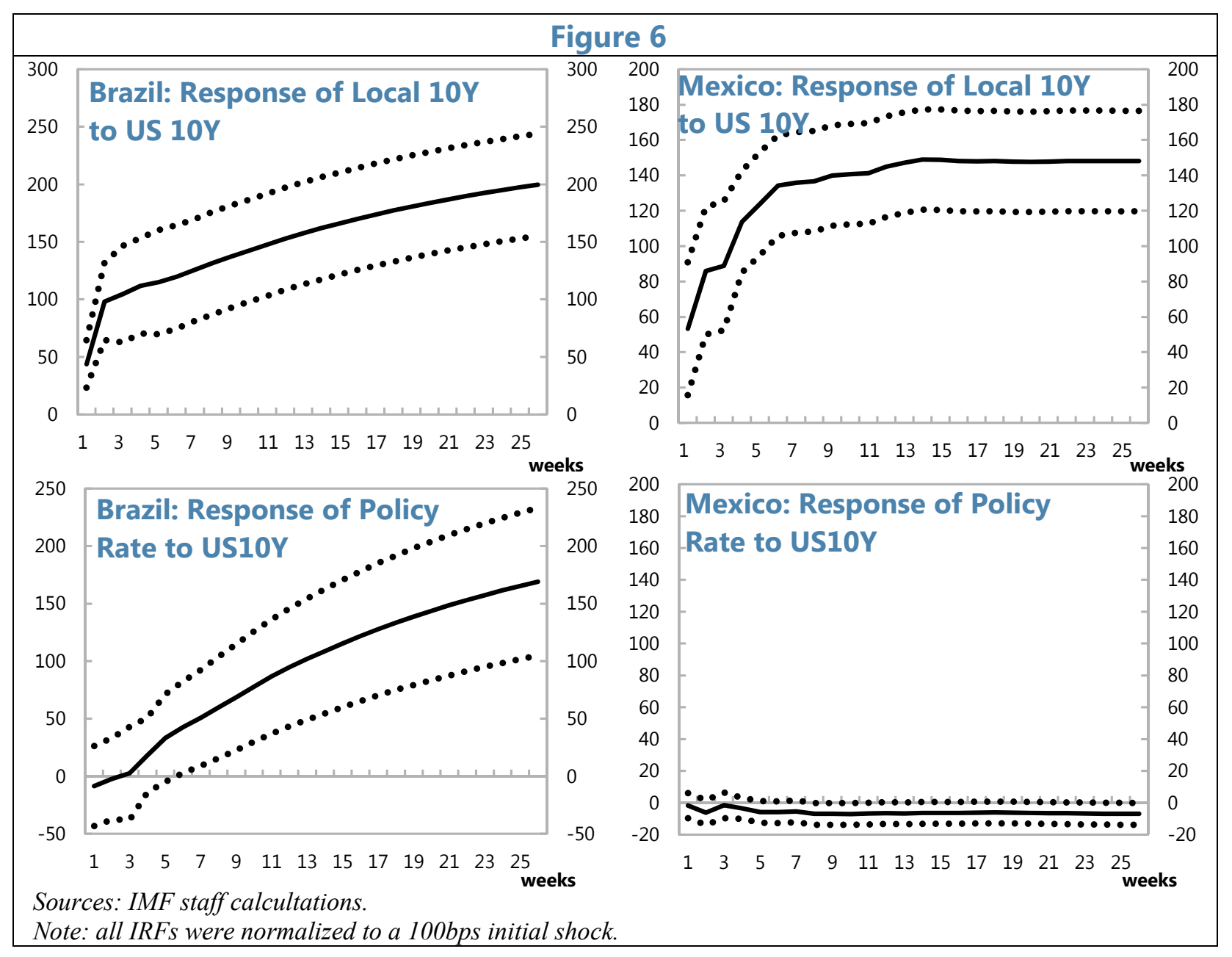

Figure 7

Variance decomposition of Brazilian Local 10Y bonds (in percent, cu mulative decomposition per week)

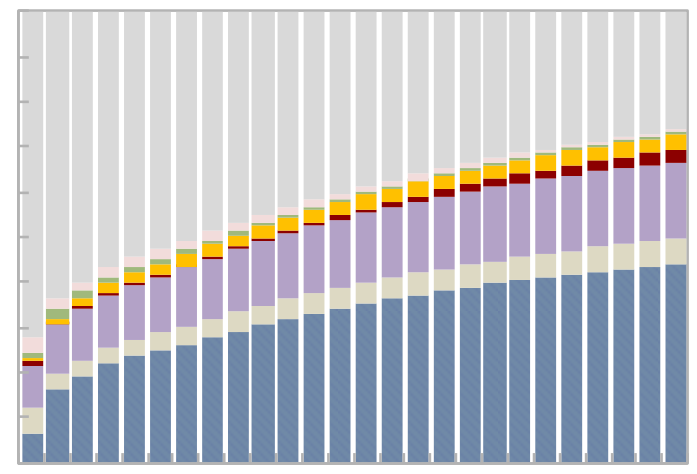

$\begin{array}{lllllllllllll}1 & 3 & 5 & 7 & 9 & 11 & 13 & 15 & 17 & 19 & 21 & 23 & 25\end{array}$
Variance decomposition of Mexican Local 10Y bonds (in percent, cu mulative deco mposition per week)

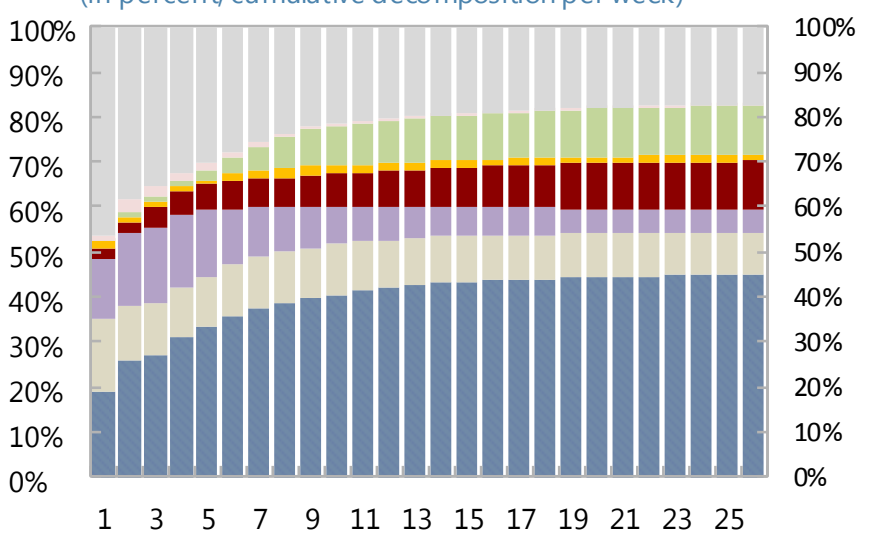

Local 10Y XR Implied Volatility $\square$ Policy Rate Inflation Expectations $\square$ Embig Country - Global $\backsim$ CDS VIX $\square$ US 10Y Source: IMF staff calcultations. 


\section{B. Observed and Model-Based Yield Estimates around "Tapering Talk"}

We examine changes in sovereign bond yields around the Fed tapering remarks - both the dynamics in the weeks preceding the event of May 21, 2013, as well as the subsequent response of the yields. This exercise illustrates important features of how these bond markets reacted differently to rising U.S. yields, and in particular, how much yields were predicted to increase, and the degree to which yields overshot their model-based equilibrium values.

For these purposes, we assess the in-sample model fit of local-currency bond yields for each country using estimated parameters and historical values for all other variables (Figure 8). The lagged values of the local curve yield are model-based predictions from previous periods. The in-sample fit for both countries is good, with the actual and fitted yields closely tracking each other over time.

\section{Contrasting initial market conditions in Brazil and Mexico}

Initial market conditions in these countries were different in the period immediately before the tapering remarks, reflecting distinct economic prospects in each of them. In Brazil, actual and fitted yields increased during the preceding three months by about 100 basis points. This largely reflected domestic factors: a perception of higher country-specific risk as spreads on both the sovereign CDS and the relative EMBI index had widened (Figure 9); and market expectations of policy interest rate hikes, including the beginning of a monetary policy tightening cycle with a 25-basis points hike in April, 2013.

In contrast, both actual and fitted yields in Mexico were steadily declining in the three months preceding the tapering remarks. This was also due mainly to domestic factors, notably the decline in the country-specific risk as reflected in lower EMBI spreads. Market optimism about the post-election reform agenda, and ongoing momentum for Mexico's inclusion in a widely tracked global bond index (Citi's WGBI) since June 2010, may also explain part of this dynamic. Another important observation is that actual yields were 50 basis points lower in Mexico than predicted by the model at the onset of the tapering talk. This suggests some undershooting or excessively low yields - compared to model predictions - just before yields began to rise.

\section{Overshooting yields relative to fundamentals}

A second key distinction between the two countries is the post-May 21, 2013 response of their sovereign yields to the U.S. shock. The model predicts a rise in yields of approximately 200 basis points and 150 basis points in the cases of Brazil and Mexico, respectively. The key driver of this rise is the significant increase in the yield on the 10-year U.S. Treasury. Actual yields for both countries overshot (and subsequently converged back to) the model's predictions but the overshooting was much larger for Brazil, notwithstanding an initial condition in which Brazil's yields were closer to the model-based "fair value". Figure 8 shows that Brazil overshot by 155 basis points (June 25, 2013) and later by 84 basis points (August 15, 2013). In contrast, Mexico overshot by 47 basis points and 33 basis points around these two dates, respectively. In both cases, the divergence from the model's 
prediction was short-lived but these overshooting episodes were reflected in elevated volatility that raised concerns about disorderly market adjustments. ${ }^{11}$
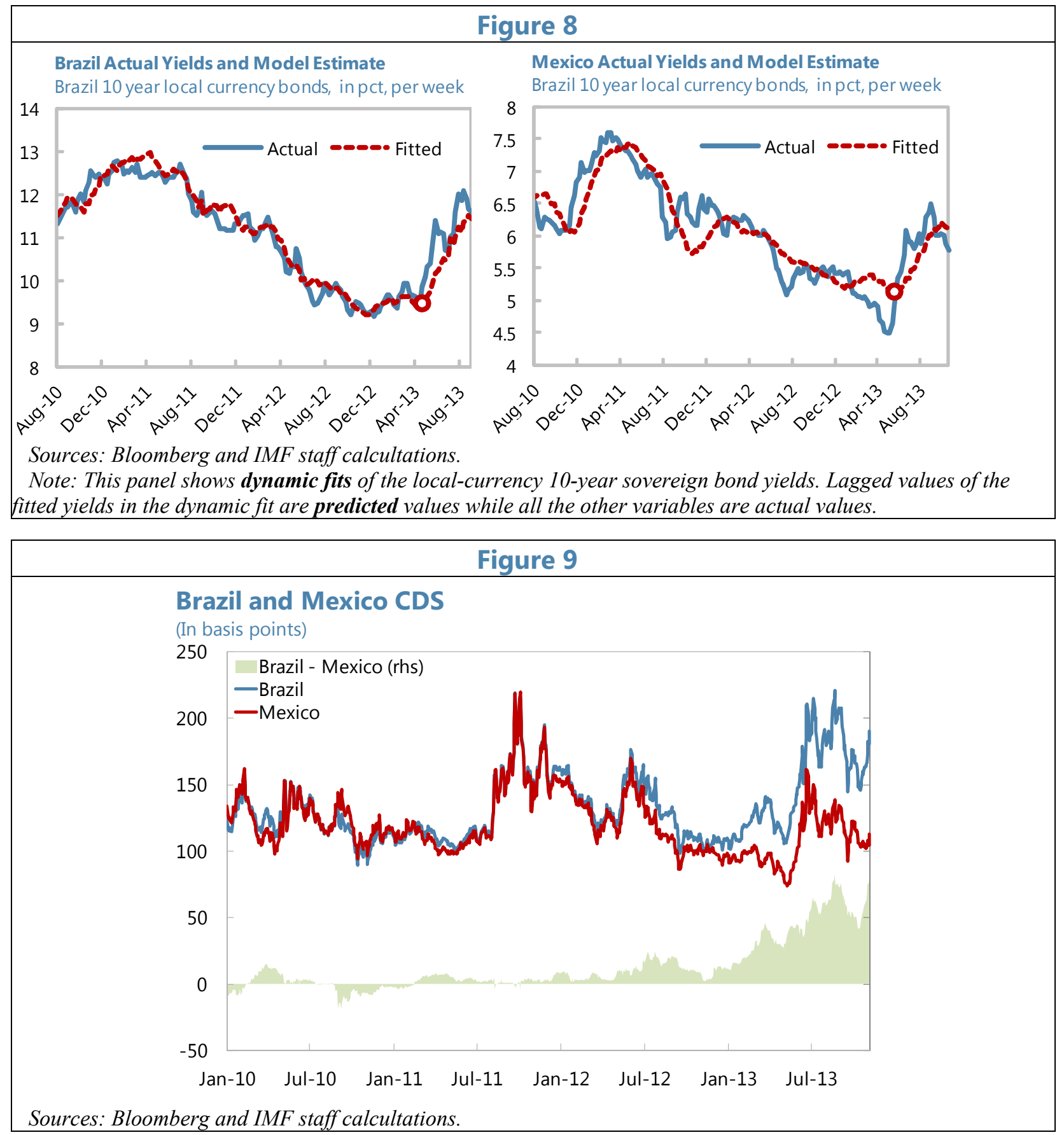

\footnotetext{
${ }^{11}$ Our specification cannot explain why yields overshot since by construction the latter is a residual from our model. We recognize the possibility of misspecification with missing explanatory variables. However, even after the inclusion of short-term factors that could drive sharp moves in local-currency asset prices, such as risk preferences (VIX) and exchange rate uncertainty (implied FX volatilities), the model was unable to adequately explain this overshooting. Another possible explanation is that markets react non-linearly to domestic and external factors during periods of elevated uncertainty.
} 


\section{Counterfactual Analysis}

To better assess what might be the implications of a sustained rise in U.S. Treasury yields, we ran various post-tapering remark scenarios for local-currency sovereign bond markets. The basic idea is to construct counterfactuals that help to identify what the model would predict for yields during the projection period if external factors and/or domestic fundamentals were unchanged.

\section{Scenario 1-Unchanged U.S. Treasury Yields}

Our first scenario uses the estimated parameters and the actual values for all of the variables with the exception of the local-currency sovereign bond yields (which are fitted by the model) and the U.S. Treasury yield, which is fixed at its level of 2.2 percent on May 21, 2013. This does not entirely isolate the model from the effects of Treasury changes, as some of the changes in historical values of the other variables - such as the CDS spreads - after the tapering remarks may reflect the impact of rising U.S. yields (the indirect effects). It does, however, control for the direct impact of Treasuries on local-currency sovereign bond yields. This scenario is shown by the thick black line in Figure 10.

Again, there are striking differences between the two countries. For Brazil, the model predicts that the local-currency yields would have continued to increase even if U.S. Treasuries had remained unchanged. Between May 21, 2013 and the peak in actual yields about three months later, the model predicts a rise of about 100 basis points in line with the pace of increasing yields observed before the tapering remarks. This clearly indicates that domestic factors played an important role in pushing local-currency sovereign yields higher. For Mexico, the model's predicted local-currency yields are broadly unchanged if we keep Treasuries fixed. This suggests that domestic factors were stable after May 21, 2013, and their contribution to the change in Mexican sovereign bond yields was relatively small.

\section{Scenario 2-Unchanged Domestic Fundamentals}

Our second scenario sets all domestic variables at their May 21, 2013 values, including policy rates, sovereign CDS spreads, and relative EMBI spreads. The U.S. Treasury takes its historical values so this scenario is effectively isolating the direct impact of rising U.S. yields on each country's long-term sovereign yields. For both countries, the model predicts an elevation in local-currency yields, confirming the key role of the U.S. benchmark. For Brazil, the model predicts a 150-basis points hike in yields to the September 2013 peak. This compares with model-based estimates of an increase of 100 basis points for Mexico. These findings underscore the results from the impulse response functions discussed in Section IV, suggesting that the direct impact of U.S. Treasury yields was higher in the case of Brazil. 


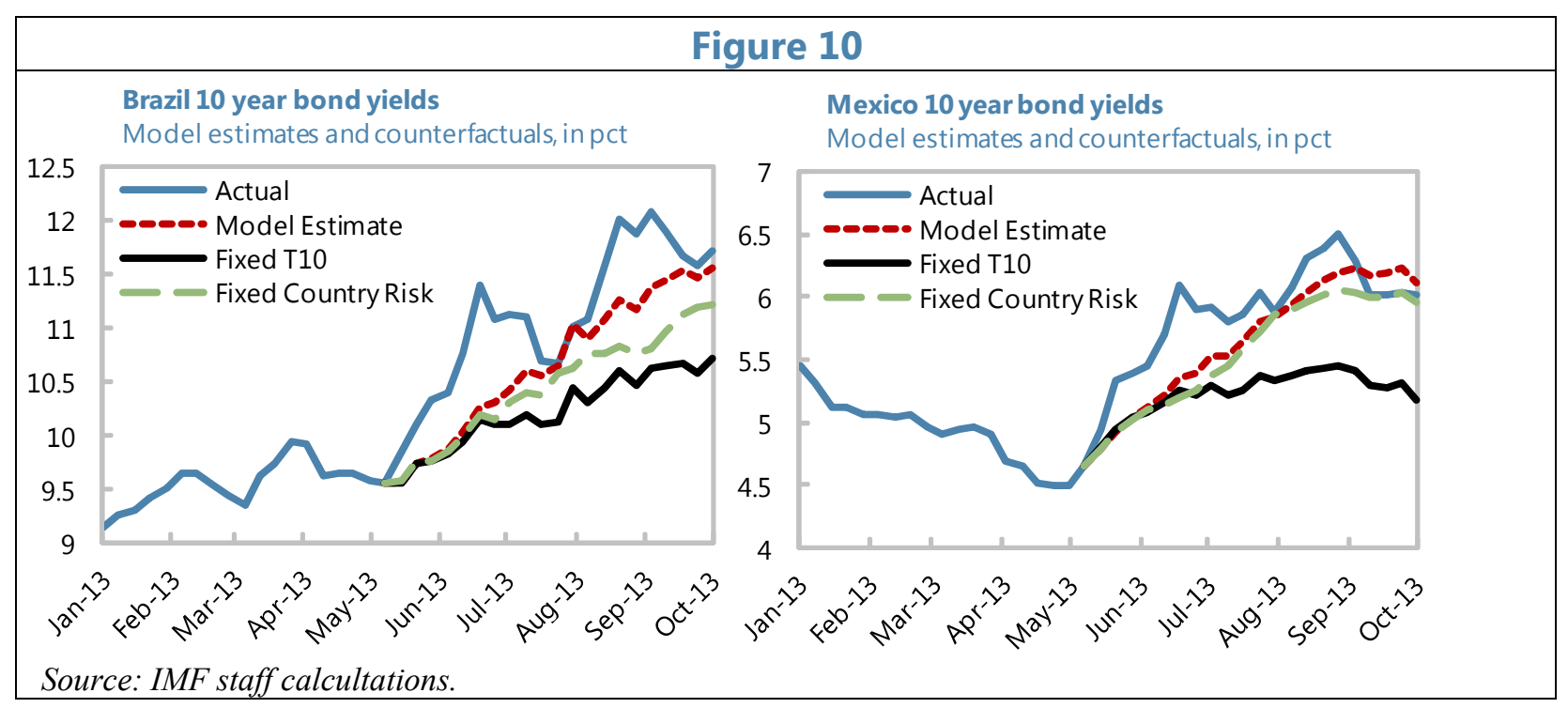

\section{AnAlysis of CoIntegration ANd Long-Run EQUILIBRIA}

The VECM proposed in this paper also allows us to estimate the long-run equilibria for Brazil's and Mexico's 10-year local-currency sovereign yields based on the explanatory variables mentioned above. Given the structure of the models, when these variables are disturbed and move away from their respective steady states, the systems are "pushed" back to their long-run equilibrium positions. In the VECM equation (1), $\beta^{\prime} y_{t-1}$ denotes the residual of the long-run equilibrium between cointegrated endogenous variables. When the residual $(z)$ from the long-run cointegration equation is different from zero, the cointegrated variables are out of long-run equilibrium (Lütkepohl, 2005). Such a residual will interact with $\alpha$, which denotes the speed of adjustment towards equilibrium when the system is not at its steady state.

Equations (2) and (3) below report the long-run relationship for Brazil and Mexico, respectively, along with the $t$-values for each of the coefficients.

$$
\begin{aligned}
& z_{t-1}^{b r a}=l_{t-1}^{b r a}-1.71 u_{t-1}-.02 c_{t-1}^{b r a}-.01 s_{t-1}^{b r a}-.23 p_{t-1}^{b r a}-.82 e_{t-1}^{b r a}-8.85 \\
& {[-5.71] \quad[-4.74] \quad[-2.93] \quad[-2.46] \quad[-1.67]} \\
& \begin{array}{c}
z_{t-1}^{\text {mex }}=l_{t-1}^{\text {mex }}-1.26 u_{t-1}-.00 c_{t-1}^{\text {mex }}+.01 s_{t-1}^{\text {mex }}-.68 p_{t-1}^{\text {mex }}-.2 e_{t-1}^{\text {mex }}-2.81 \\
{[-21.92][-1.36][-05][-3.84][-1.68]}
\end{array}
\end{aligned}
$$

In the present estimates, the speed of adjustment of Brazil's local-currency 10-year sovereign bond yields (0.11) is slightly lower than Mexico's yields (0.17), but their 95-percent confidence intervals overlap. Economically speaking, this means that approximately 12 to 16 percent of the "deviation from equilibrium" (i.e., the error originated from shocking the system) is corrected after one-time period (in the present case, after one week).

Asymptotically, it is possible to calculate that after 10 weeks more than 80 percent of the 
correction towards their respective long-run equilibria would have taken place. Thus, both yields exhibit a relatively fast return to steady state.

In a scenario analysis where the U.S. yield increases permanently 100 basis points and all other variables are held constant, our VECM suggests that Mexico's yields would need to rise by 111 basis points in order to fully offset that shock, while Brazil's yields would need to increase by 113 basis points to slip back to its long-run equilibrium. ${ }^{12}$

However, there is a difference between Mexico and Brazil during this sample period. While in Mexico changes in the U.S. 10-year yields did not have much of an impact on the shortterm (policy) rate, in Brazil the policy rate responded to innovations in the U.S. Treasuries (Appendix IV). For such a reason, a ceteris paribus scenario in which we shock the U.S. Treasury yields and hold other variables constant will not show the expected value of the local-currency 10-year sovereign bond yields at the new steady state. Rather, the new steadystate for the long-run relationship between the Brazilian local-currency yields and the other variables should consider both the direct and indirect impacts of the U.S. Treasuries, as the latter affect the local-currency yields through other variables-particularly the policy rate.

Possible explanations for the different sizes of their responses may be intrinsically related to the determinants of risk premium in each country. For instance, distinct market microstructure conditions (such as the lower liquidity of Brazil's local-currency long-term sovereign bond market), credit risks (as gauged by sovereign credit ratings), risk-adjusted returns (e.g. the Sharpe ratio for Brazil was 8.8 percent during the sample period versus 11.4 percent for Mexico), among other factors, may help to explain these differences.

\section{STATISTICAL RobUSTNESS}

We are fully aware of the limits of working with a VECM, which assumes long-run equilibria between the variables in a relatively short sample. Even though we found strong evidence for cointegration even when using more conservative trace statistics as proposed by Hjalmarsson and Österholm (2007), it is possible that those results are a product of the sample we are working with.

To address these concerns, we estimate an alternative model. We ran a simple VAR, taking first differences of all the endogenous variables to make sure that all the variables in the model have stationary properties. The model is specified in equation (4) below:

\footnotetext{
${ }^{12}$ The results presented could be subject to issues of proportionality, as the average yield for Brazil has been historically higher than the average yield for Mexico over the sample period. We understand that, from a policy and economic standpoint, level changes in yields are more intuitive and relevant than proportional changes with respect to initial levels. To illustrate this, imagine that U.S. bond yields are at 200 basis points while Brazilian bond yields stand at 1000 basis points. If the U.S. bond yields were to double and elasticity were 1, this would imply that Brazilian bond yields would increase to 2000 basis points. Due to initial level differences in our imaginary illustration, even a 0.5 elasticity would mean that a 200-basis points increase in the U.S. yields would lead to a 500-basis points rise in the Brazilian yields. For such a reason, using elasticities ends up not being as straightforward or economically intuitive as using levels of yields.
} 


$$
\Delta Y_{t}=\sum_{i=1}^{p} A_{i} \Delta \mathrm{Y}_{\mathrm{t}-\mathrm{i}}+C+\epsilon_{t}
$$

where $\mathrm{Y}_{\mathrm{t}} \equiv[u, v, c, s, p, i, l]^{\prime}$ is a $m$-dimensional vector of endogenous variables; $\mathrm{A}$ is a $(m \mathrm{x}$ $m$ ) matrix of coefficients determining the dynamics of the endogenous variables; $\mathrm{C}$ is a vector of constants; $\epsilon$ is a vector of error terms. The Cholesky ordering and lag-lengths for Brazil and Mexico are identical as those used for the VECM.

In order to make the results of the VAR comparable with those we have estimated with the VECM, we accumulated the IRFs and assessed the impact on the level of the different variables. We focused particularly on the following IRFs: (a) the response of local-currency 10-year sovereign bond yields to changes in the U.S. 10-year bond yields; (b) the response of the policy rate to changes in the U.S. 10-year bond yields; and (c) the response of localcurrency 10-year sovereign bond yields to changes in the policy rate. For both countries the point estimates for the VAR-based IRFs are very similar and all of them lie well within the 95-percent confidence interval of the original VECM as seen in Figure 11 below. 


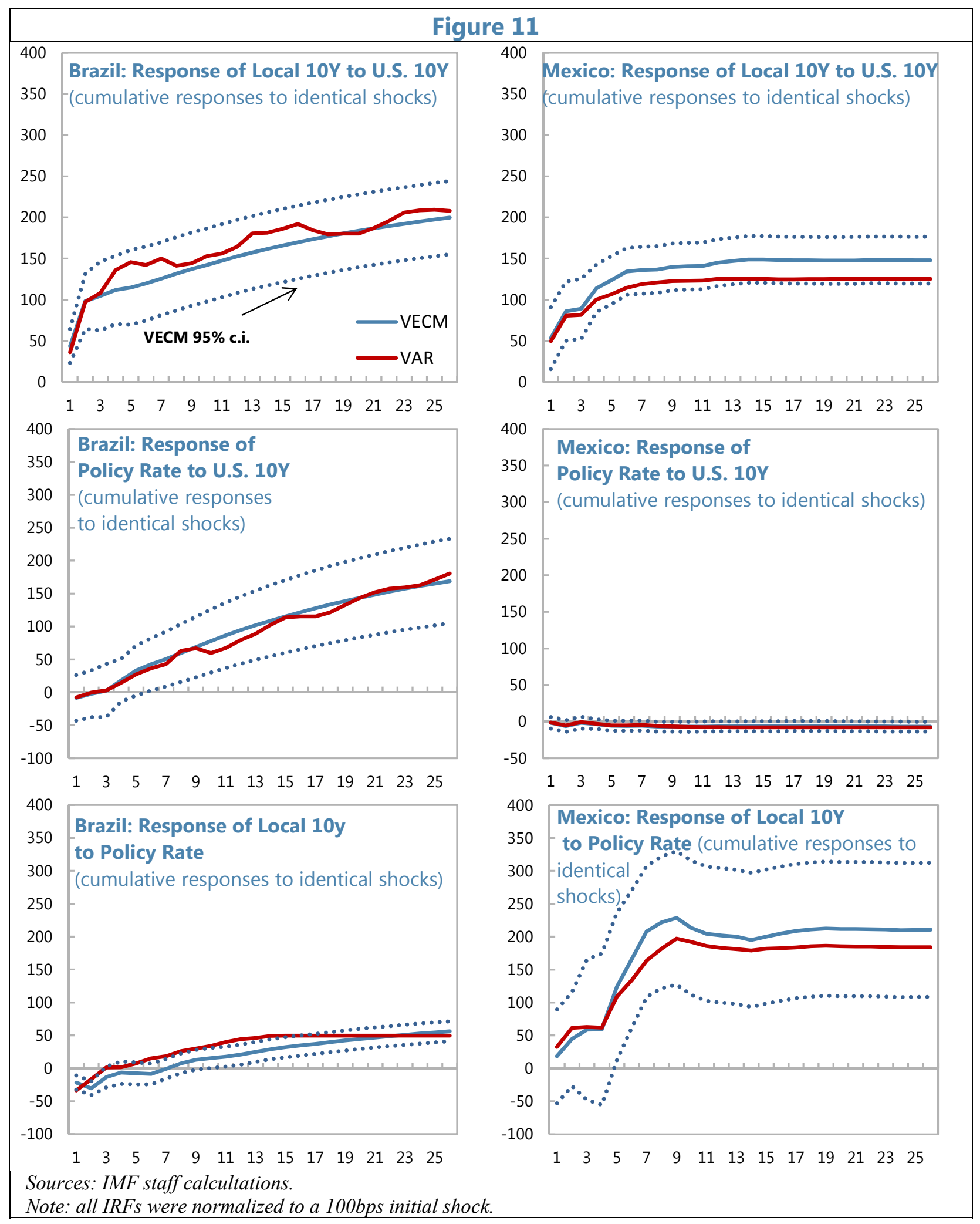

CInternational Monetary Fund. Not for Redistribution 


\section{DisCuSSION AND POLICY IMPLICATIONS}

What explains the larger response in Brazil's yields compared to Mexico's yields during the period 2010-13? Below we discuss a number of possible explanations.

\section{Global financial integration}

More financially integrated markets are likely to exhibit greater sensitivity to global factors. This might be due to the presence of non-resident investors that arbitrage expected real yields across fixed-income markets - for example, a higher real yield on the global benchmark would trigger a reallocation away from emerging markets until local yields rise to the point that the risk-adjusted expected real return is equivalent to the benchmark. However, this cannot explain the differences between Brazil and Mexico. Both markets are well integrated with open capital accounts (albeit subject to capital flow management measures in Brazil) and substantial foreign investor participation in local debt markets. Foreign holdings of outstanding local-currency sovereign debt are actually higher in "lower sensitivity" Mexico at 35 percent compared to about 17 percent in Brazil (Figure 12) suggesting that while foreign participation may increase sensitivity for countries over time it is unable to explain the recent difference between Mexico and Brazil.

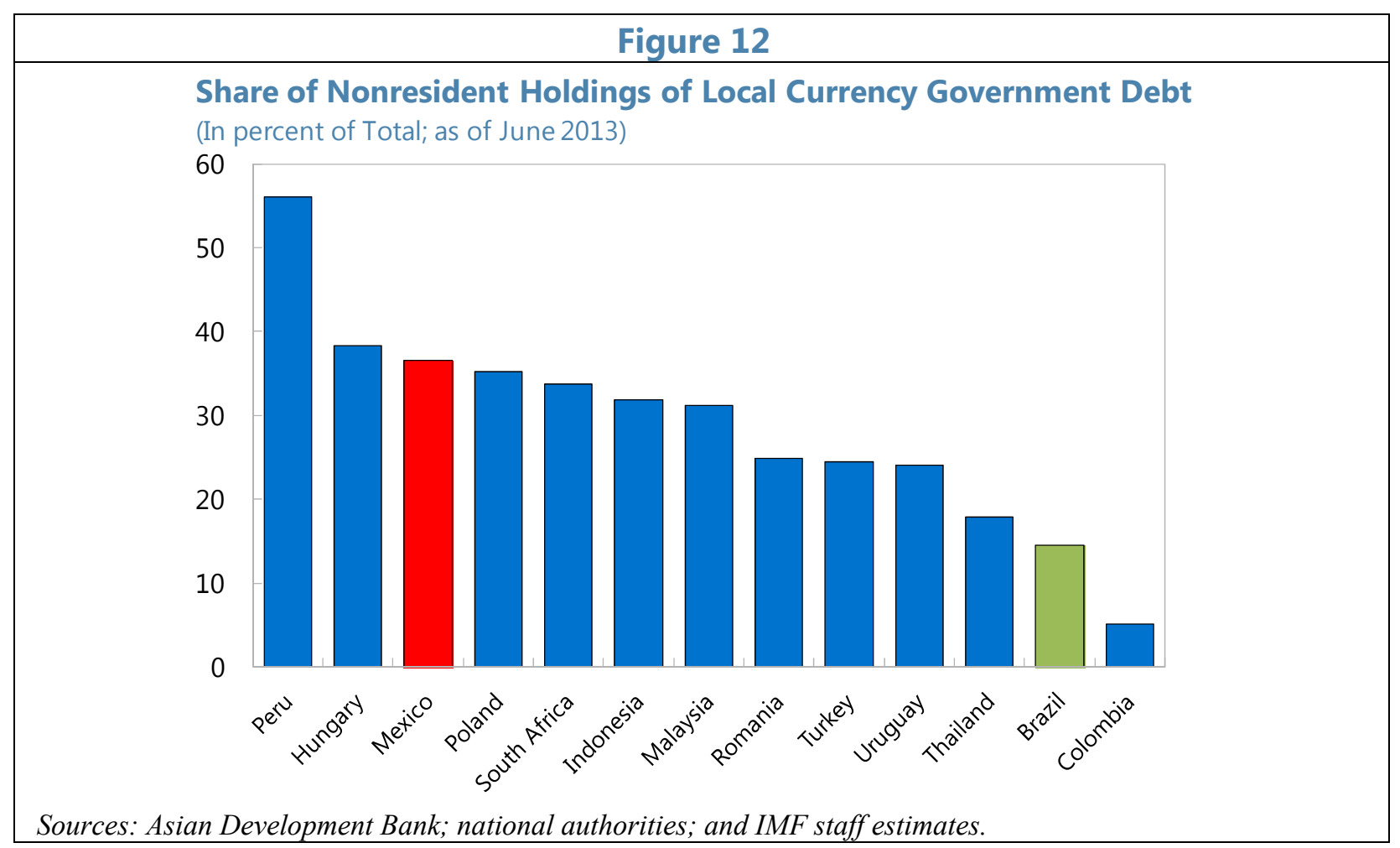




\section{Domestic fundamentals}

A second possibility is that U.S. Treasury yields are interacting importantly with domestic fundamentals. Consider, for example, that markets perceive that macroeconomic fundamentals of a particular country (such as its fiscal or external position) have weakened. This could increase the direct impact of Treasuries, with rising U.S. yields having larger effects without further affecting domestic factors, such as country-specific risk or policy rates.

Alternatively, weaker perceived fundamentals could amplify the change in bond yields of the Treasury shock through an indirect impact. Tighter financing conditions, evident in higher global benchmark yields, may encourage markets to require a higher risk premium to hold these countries' assets and fund their fiscal deficits. In other words, domestic factors themselves might also change in response to higher yields, including a shift in the price of country risk (a higher CDS or EMBI spread). A change in global financial conditions may also lead to domestic policy adjustments that also affect local-currency yields.

For example, if higher U.S. yields lead to an unexpectedly large exchange rate depreciation and higher inflation due to pass-through effects, the policy rate may have to rise to stabilize inflation expectations. The less securely anchored are inflation expectations, the larger these effects are likely to be. An examination of impulse responses for these variables to U.S. yields can help us understand the relative importance of the direct and indirect impacts.

\section{Policy Implications}

The analysis in previous sections suggests that the transition from a prolonged period of global monetary easing to an environment marked by higher rates and steeper yield curves in the U.S. may be a jagged one, as witnessed in the May 2013 event. Policy makers in Brazil and Mexico, therefore, have to contend with potential spillovers, which are likely to lead to higher government bond interest rates and bouts of volatility. If the transition occurs smoothly as occurred in December 2015 (when the Fed raised rates for the first time in nearly a decade), both countries have enough experience and tools to manage the changes. While our analysis does not specifically address the policy makers' reaction functions, there are some useful general lessons that can be drawn from the experiences of heightened market volatility over the last few years.

Countries should use the periods of calm — or when markets are amenable to taking on more risk - to build the flexibility necessary to deal with surprise events. Markets often differentiate countries according to their fundamentals, and the pass-through rate of a rise in U.S. 10-year yields to local-currency bond yields is likely to be larger and more sustained for countries perceived to be weaker on those criteria. In fact, there seems to be no substitute to maintaining strong macroeconomic and financial fundamentals and policies, which engenders confidence in policy frameworks.

The tapering talk experience in Mexico and Brazil suggests that market participants are more willing to hold on to positions if they are confident in the ability to hedge risks. Fostering 
deep liquid hedging markets in currencies and interest rates allows investors to hedge both interest rate and foreign currency exposures, mitigating the need to significantly reduce exposures to government bonds. In the case of Mexico, the ability to hedge those risks did not lead to a material change in the foreign holdings of Mexican government bonds, which remained at record highs.

Policymakers can also use foreign exchange and debt management operations to alleviate stresses in the functioning of the FX and sovereign bond markets. This often facilitates the hedging process and reduces market participants' worries regarding very large, abrupt changes in valuation that could dramatically alter the perception of the trade-off between risk and reward. A key lesson from these activities is that policy makers need to provide investors with the flexibility to adjust to surprises in domestic bond markets. These operational tools should be complemented with a clear line of communications with market participants to gauge demand and enhance policy makers' awareness of alternative sources of financing. Keeping some fiscal buffer or space to partially accommodate sudden shocks can also help. Moreover, it is important to maintain credibility with market participants.

While FX intervention has been widely studied and debated, there has been less focus on the role of public debt management. Since 2008, public debt managers have generally responded in three ways: (a) by closing funding gaps with alternative resources (like targeted bonds sales to domestic pension funds; by replacing borrowing from the private sector with excess liquidity from the public sector; by borrowing from multilaterals; and by encouraging a diversified foreign-investor base); (b) by shortening the average time-to-maturity of the outstanding debt; and (c) by resorting to debt buybacks and exchanges of fixed-rate liabilities by floaters. ${ }^{13}$ Some countries complemented debt management operations with coordinated support from central banks. ${ }^{14}$

Interventions of this nature were observed during the period of market distress following the Fed's tapering remarks in May 2013. For instance, Mexican authorities modified their issuance mix to allow investors to reduce their duration exposure. Meanwhile, that government issued more short-term paper in lieu of longer-term paper, and both the government and governmental agencies increased somewhat their offering of floating rate debt. In July 2013, the Mexican government diversified its investor base by issuing in the Japanese yen market, which appeared to be less affected by concerns with the U.S. Fed's tapering comments.

\footnotetext{
${ }^{13}$ See Anderson, Silva, and Velandia-Rubiano (2010, 2013) for a comprehensive discussion of these debt management strategies across EMs.

${ }^{14}$ See IMF, 2011.
} 


\section{CONCLUDing REMARKS}

In this paper we examined the transmission of changes in the U.S. monetary policy to Brazil and Mexico's local-currency sovereign bond yields. Using vector error-correction models, which encompass both long-term and short-term relationships, we found that the U.S. 10year bond yield was a key driver of long-term yields in Brazil and Mexico during 2010-13. Our econometric results suggest that Brazilian yields were more sensitive to U.S. shocks than Mexican yields in the sample period. Remarkably, we found that shocks to U.S. long-term yields were amplified by changes in the policy rate in Brazil, but not in Mexico.

We also compared local-currency sovereign bond yield dynamics around May 2013, the month when tapering expectations shifted. Empirical evidence shows that Mexican yields were below the values predicted by our econometric models in the weeks immediately before the U.S. Federal Reserve Board tapering speech, while Brazil's yields were in line with our model-based estimates.

Our counterfactual analysis suggests that yields in both countries temporarily overshot the values predicted by the model in the period following the tapering announcement. This highlights the need for policy makers in emerging markets to contend with potential spillovers from shifts in monetary policy expectations in the U.S., which are likely to lead to higher government bond interest rates and bouts of volatility.

Markets often differentiate countries according to their macro and financial fundamentals. The pass-through rate of a rise in U.S. long-term yields to these countries' local-currency bonds is likely to be larger and more sustained for those perceived to be weaker in such criteria. Therefore, emerging markets should seize the periods of calm to build the flexibility necessary to deal with these events. While there seems to be no substitute to maintaining strong macroeconomic and financial fundamentals and policies, in the present paper we discuss debt-management strategies that help to contend with spillovers from the U.S. monetary policy at times of market distress. 


\section{ApPendix I. Pre-Estimation Tests}

Before applying our vector error correction model (VECM), we conducted a set of statistical tests to see if this method is appropriate for the analysis. Augmented Dickey-Fuller Unit Root tests (Dickey \& Fuller, 1979) rejected the null hypothesis of a unit root for the implied volatility of the exchange rate $(i)$. For the VIX index $(v)$, even though our tests report borderline results, the literature underscores that the VIX tends to be mean reverting over the long run (Duan \& Yeh, 2011), which suggests that our tests could be suffering from selection bias from our short time frame. We could not reject the null hypothesis for a unit root for any of the other variables in the 90 percent confidence interval.

The next step was to determine which variables should be in either side of our equation. After performing Granger Causality tests, we found sufficient evidence that causality runs in both directions for many of the variables included in the model. Thus, we concluded that using a single equation model would suffer from endogeneity problems. Doing so would mean losing the feedback effects between the different variables and reporting biased coefficients. We then opted for a vector autoregressive (VAR) model, with multiple simultaneous equations for each period $t$. In order to determine the appropriate lag length for our model we performed standard lag-determination tests. The results are reported in Table 1.

Finally, we tested for cointegration using Johansen's tests (Johansen, 1991) with the appropriate lag-length specification and found strong evidence of cointegration. For both Brazil and Mexico, we found evidence of at least one cointegrating relationship between the I(1) variables. As the variables are cointegrated, they share a long-run relationship that tends towards equilibrium. In this case, first differencing the variables and setting the model as a VAR could be a misspecification (Engle and Granger, 1987). Rather, an error correction term that accounts for the long-run equilibrium should be included (Granger, 1981).

Due to the limited power of unit root tests and some theoretical considerations, there is a debate about whether or not interest rates are cointegrated. As pointed out by Cochrane (2001), unit root tests often fail to reject the null hypothesis of a unit root in finite samples. But there are theoretical reasons to think that interest rates are stationary at the very long run. In fact, there are about 25 years of literature that follows the statistical tests and treats interest rates as integrated series. In their seminal paper on cointegration, Engle and Granger (1987) argued that short- and long-term interest rates are examples of a cointegrated system. Unsurprisingly, the expectations theory, one of the most common approaches to studying yield curves, rely on the assumption that short- and long-term rates are cointegrated series with a stationary term premium. Other examples of nominal interest rates used in a cointegration framework include Lütkepohl and Reimers (1992), Johansen and Juselius (1992), Hall, Anderson, and Granger (1992), and Pesaran and Shin (1996).

We chose to take the latter approach and analyzed nominal interest rates as a cointegrated system. Nevertheless, given the on-going debate, we recognize that it is possible that interest rates are highly-persistent near-integrated series with their roots being close-to-unity. In such 
case, standard tests are simply not powerful enough to differentiate between highly-persistent $\mathrm{I}(0)$ and $\mathrm{I}(1)$ data.

With that in mind, we apply the cointegration test for near-unit root variables designed by Hjalmarsson and Österholm (2007). The test uses more conservative critical values for Engle-Granger residual tests under the assumption that the potentially cointegrated variables are near-integrated. We used such critical values to assess if our systems of variables are cointegrated under those assumptions. For both the cases of Brazil and Mexico, we found evidence for cointegration even using the aforementioned conservative critical values (see Appendix II for details and further explanation).

Table A1.

Augmented Dickey-Fuller Unit Root Tests

\begin{tabular}{|c|c|c|}
\hline & \multicolumn{2}{|c|}{$p$-values } \\
\hline & Brazil & Mexico \\
\hline VIX & \multicolumn{2}{|c|}{$0.10^{*}$} \\
\hline U.S. 10Y & \multicolumn{2}{|c|}{0.55} \\
\hline Embig Local - Global Spread & 0.51 & 0.48 \\
\hline Policy Rate & 0.22 & 0.97 \\
\hline Implied Volatility & $0.00 * * *$ & $0.05^{* *}$ \\
\hline Local 10Y & 0.61 & 0.52 \\
\hline CDS & 0.12 & 0.14 \\
\hline
\end{tabular}

Null Hypotesis: variable has a unit root

Significant at $10 \%:\left({ }^{*}\right) ; 5 \%\left({ }^{* *}\right) ; 1 \%\left({ }^{* \star *}\right)$ levels

Table A2.

Brazil Granger Causality Tests

Embig Local -

\begin{tabular}{|c|c|c|c|c|c|c|c|}
\hline Brazil & VIX & U.S. 10Y & $\begin{array}{l}\text { Global } \\
\text { Spread }\end{array}$ & Policy Rate & $\begin{array}{l}\text { Implied } \\
\text { Volatility }\end{array}$ & Local 10Y & CDS \\
\hline VIX & - & 0.21 & $0.08 *$ & $0.00^{* * *}$ & $0.10^{*}$ & $0.02^{* *}$ & 0.98 \\
\hline U.S. $10 Y$ & 0.68 & - & 0.26 & $0.00 * * \star$ & 0.94 & $0.00 * * *$ & 0.66 \\
\hline Embig Local - Global Spread & 0.93 & $0.08^{*}$ & - & $0.00^{\star * *}$ & 0.51 & $0.00^{* * *}$ & 0.62 \\
\hline Policy Rate & $0.00^{\star * *}$ & 0.32 & $0.04^{* *}$ & - & $0.09 *$ & $0.00 * \star \star *$ & 0.95 \\
\hline Implied Volatility & 0.79 & 0.84 & $0.08^{*}$ & $0.02^{* *}$ & - & $0.08^{*}$ & 0.81 \\
\hline Local 10Y & $0.08^{*}$ & 0.95 & 0.13 & $0.00^{\star * *}$ & 0.38 & - & 0.76 \\
\hline CDS & 0.24 & 0.71 & 0.40 & 0.31 & 0.21 & 0.75 & - \\
\hline
\end{tabular}


Table A3.

Mexico Granger Causality Tests

Embig Local -

\begin{tabular}{|c|c|c|c|c|c|c|c|}
\hline Mexico & VIX & U.S. 10Y & $\begin{array}{l}\text { Global } \\
\text { Spread }\end{array}$ & Policy Rate & $\begin{array}{l}\text { Implied } \\
\text { Volatility }\end{array}$ & Local 10Y & CDS \\
\hline VIX & - & 0.21 & $0.09 *$ & 0.49 & 0.18 & 0.44 & $0.09^{*}$ \\
\hline U.S. 10Y & 0.68 & - & 0.81 & 0.35 & 0.88 & $0.1^{*}$ & 0.78 \\
\hline Embig Local - Global Spread & 0.98 & 0.41 & - & 0.88 & 0.98 & $0.08^{*}$ & 0.86 \\
\hline Policy Rate & 0.97 & 0.40 & 0.71 & - & 1.00 & 0.65 & 0.41 \\
\hline Implied Volatility & 0.25 & 0.13 & $0.10^{*}$ & 0.60 & - & 0.71 & 0.49 \\
\hline Local 10Y & $0.03^{* *}$ & $0.02^{* \star}$ & 0.36 & 0.59 & 0.29 & - & 0.70 \\
\hline CDS & $0.01^{* * *}$ & $0.01^{\star \star \star}$ & $0.07^{*}$ & 0.97 & 0.33 & 0.91 & - \\
\hline
\end{tabular}

Null Hypotesis: row variable does not cause cause column variable

Significant at $10 \%:\left({ }^{*}\right) ; 5 \%\left(^{(\star)}\right) ; 1 \%\left({ }^{* * *}\right)$ levels

Table A4.

\begin{tabular}{|c|c|c|c|c|c|c|}
\hline \multicolumn{7}{|c|}{ Brazil Lag Length Tests } \\
\hline Lag & LogL & LR & FPE & AIC & SC & HQ \\
\hline 0 & -2762.1 & NA & 489372 & 32.966 & 33.096 & 33.019 \\
\hline 1 & -1483.7 & 2435.219 & $0.215^{*}$ & 18.381 & $19.370^{*}$ & $18.751^{*}$ \\
\hline 2 & -1435.4 & 87.830 & 0.218 & 18.339 & 20.291 & 19.131 \\
\hline 3 & -1390.0 & 78.976 & 0.229 & $18.329^{*}$ & 21.245 & 19.543 \\
\hline 4 & -1364.6 & 42.028 & 0.308 & 18.662 & 22.437 & 20.194 \\
\hline 5 & -1309.9 & 86.010 & 0.294 & 18.594 & 23.280 & 20.495 \\
\hline 6 & -1283.9 & 38.603 & 0.400 & 18.868 & 24.465 & 21.140 \\
\hline 7 & -1236.2 & 66.983 & 0.427 & 18.884 & 25.392 & 21.525 \\
\hline 8 & -1191.2 & 59.549 & 0.478 & 18.931 & 26.350 & 21.942 \\
\hline 9 & -1137.9 & 65.967 & 0.495 & 18.880 & 27.210 & 22.261 \\
\hline 10 & -1090.1 & 55.145 & 0.563 & 18.895 & 28.136 & 22.645 \\
\hline 11 & -1028.2 & $66.367^{*}$ & 0.557 & 18.740 & 28.893 & 22.861 \\
\hline 12 & -972.0 & 55.557 & 0.611 & 18.654 & 29.718 & 23.145 \\
\hline
\end{tabular}

* indicates lag order selected by the criterion

LR: sequential modified LR test statistic (each test at $5 \%$ level)

FPE: Final prediction error

AIC: Akaike information criterion

SC: Schwarz information criterion

HQ: Hannan-Quinn information criterion 
Table A5.

\begin{tabular}{|c|c|c|c|c|c|c|}
\hline \multicolumn{7}{|c|}{ Mexico Lag Length Tests } \\
\hline Lag & LogL & LR & FPE & AIC & SC & HQ \\
\hline 0 & -2264.3 & NA & 949 & 26.721 & 26.850 & 26.773 \\
\hline 1 & -914.1 & 2573.212 & $0.000^{*}$ & $11.413^{*}$ & $12.446^{*}$ & $11.832^{*}$ \\
\hline 2 & -880.9 & 60.559 & 0.000 & 11.599 & 13.536 & 12.385 \\
\hline 3 & -837.3 & $75.992^{*}$ & 0.000 & 11.662 & 14.503 & 12.815 \\
\hline 4 & -813.2 & 39.990 & 0.000 & 11.955 & 15.699 & 13.474 \\
\hline 5 & -788.6 & 38.756 & 0.001 & 12.242 & 16.890 & 14.128 \\
\hline 6 & -757.3 & 46.646 & 0.001 & 12.451 & 18.003 & 14.704 \\
\hline 7 & -714.1 & 61.042 & 0.001 & 12.519 & 18.975 & 15.139 \\
\hline 8 & -672.7 & 55.078 & 0.001 & 12.608 & 19.968 & 15.595 \\
\hline 9 & -621.9 & 63.273 & 0.001 & 12.588 & 20.851 & 15.941 \\
\hline 10 & -587.3 & 40.317 & 0.001 & 12.757 & 21.924 & 16.477 \\
\hline 11 & -536.1 & 55.450 & 0.001 & 12.731 & 22.802 & 16.817 \\
\hline 12 & -481.4 & 54.699 & 0.001 & 12.663 & 23.639 & 17.117 \\
\hline
\end{tabular}

* indicates lag order selected by the criterion

LR: sequential modified LR test statistic (each test at $5 \%$ level)

FPE: Final prediction error

AIC: Akaike information criterion

SC: Schwarz information criterion

HQ: Hannan-Quinn information criterion

\section{Brazil}

Table A6.

\section{Brazil Johansen Cointegration Tests}

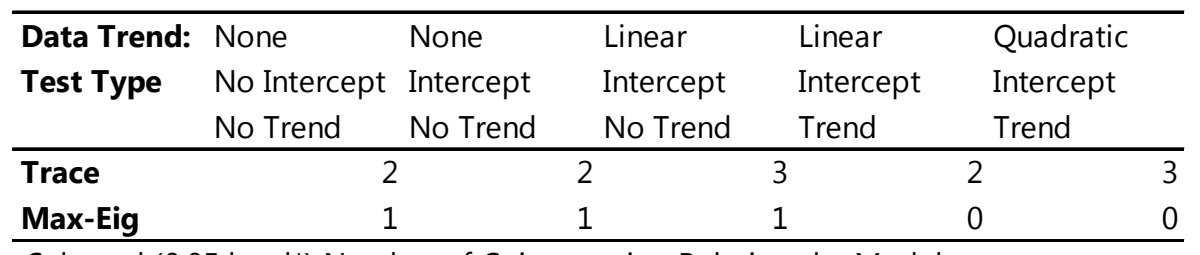

Selected ( 0.05 level*) Number of Cointegrating Relations by Model

${ }^{*}$ Critical values based on MacKinnon-Haug-Michelis (1999)

Table A7.

Brazil Johansen Cointegration Tests

Mexico

\begin{tabular}{|c|c|c|c|c|c|c|}
\hline Data Trend: & None & None & Linear & Linear & \multirow{3}{*}{\multicolumn{2}{|c|}{$\begin{array}{l}\text { Quadratic } \\
\text { Intercept } \\
\text { Trend }\end{array}$}} \\
\hline Test Type & No Intercept & Intercept & Intercept & Intercept & & \\
\hline & No Trend & No Trend & No Trend & Trend & & \\
\hline Trace & \multicolumn{2}{|c|}{2} & 2 & 2 & 2 & 2 \\
\hline Max-Eig & \multicolumn{2}{|c|}{1} & 1 & 2 & 2 & 2 \\
\hline
\end{tabular}

Selected (0.05 level*) Number of Cointegrating Relations by Model

${ }^{*}$ Critical values based on MacKinnon-Haug-Michelis (1999) 


\section{APPENDIX II. COINTEGRATION TEST FOR NEAR-INTEGRATED VARIABLES}

Near-integrated series are asymptotically stationary even though they behave as integrated series in any finite sample. They take the following form:

$$
z_{t}=\phi z_{t}+u_{t,}, \quad z_{t} \sim I(0), \quad|\phi|=1+c
$$

where $c$ is small and $\leq 0$. Hjalmarsson and Österholm (2007) developed the following residual-based cointegration test for near integrated variables. Like Phillips (1988), it assumes that the true processes of the variables of interest are highly persistent but nonintegrated-i.e., near integrated - and take the following form:

$$
z_{t}=A z_{t}+u_{t}
$$

where $A=I+T^{-1} C$ is a $m \times m$ matrix with $A=\operatorname{diag}\left(a_{1}, \ldots, a_{m}\right)$ and $C=\operatorname{diag}\left(c_{1}, \ldots, c_{m}\right)$, $T$ is the sample size, and $c_{i} \leq 0 \forall i$.

Hjalmarsson and Österholm show by simulation that the most important element to assess cointegration in that framework will be the contrast between the critical value of unit root tests of the variable put on the left-hand side of the cointegration regression and the roots of the residuals, even when other regressors are nearly integrated.

Based on the assumption (2.B) described above, they create a confidence interval for the unknown $c_{i}$ (by inverting the unit root test statistic of the variable of interest) and develop more conservative critical values for Engle-Granger tests. In their paper they provide tables with critical values for a different number of regressors and test statistics. We have used those tables for our analysis of cointegration of potentially near-integrated variables.

The practical implementation of the test has three steps. First we run a DF-GLS unit root test in the local-currency 10-year sovereign bond yields and invert the test statistic to obtain the lower bound for $c_{1}$. Then we run the cointegration regression as a Fully-Modified OLS, collect the residuals and calculate the test statistic for the residuals in the usual Engle Granger framework. Finally, we use Hjalmarsson and Österholm's table to see what is the proper critical value to determine if the residuals are stationary. If we reject the hypothesis of a unit root using the more conservative critical value, we conclude in favor of cointegration.

Even when using this more conservative framework, which assumes that the variables are nearly integrated, we find evidence in favor of cointegration (Table 2). 
Table A1.

Local 10Y DF-GLS Unit Root Tests

\begin{tabular}{|c|c|c|c|}
\hline \multirow{4}{*}{ Local 10Y } & & \multicolumn{2}{|c|}{ t-Statistic } \\
\hline & & Brazil & Mexico \\
\hline & & -1.00 & -1.09 \\
\hline & estimated $c$ & -1.47 & -1.90 \\
\hline $1 \%$ level & & \multicolumn{2}{|c|}{-2.5788} \\
\hline $5 \%$ level & & \multicolumn{2}{|c|}{-1.9427} \\
\hline $10 \%$ level & & \multicolumn{2}{|c|}{-1.6154} \\
\hline
\end{tabular}

Null Hypothesis: variable has a unit root

Table A2.

Residual-Based Cointegration Test

\begin{tabular}{lcc} 
& \multicolumn{2}{c}{$t$-Statistic } \\
\cline { 2 - 3 } & Brazil & Mexico \\
\hline Cointegration Residuals & -5.2089 & -4.81 \\
\hline Conservative Critical Value & & \\
with 4 regressors and a & -4.730 & -4.730 \\
constant, given estimated c & & \\
above & & \\
Standard Critical Value (1\%) & -3.4696 \\
\hline
\end{tabular}

Null Hypothesis: variable has a unit root 


\section{APPEndiX III. Time Series Plots}

Figure A1. Brazil: Domestic Time Series
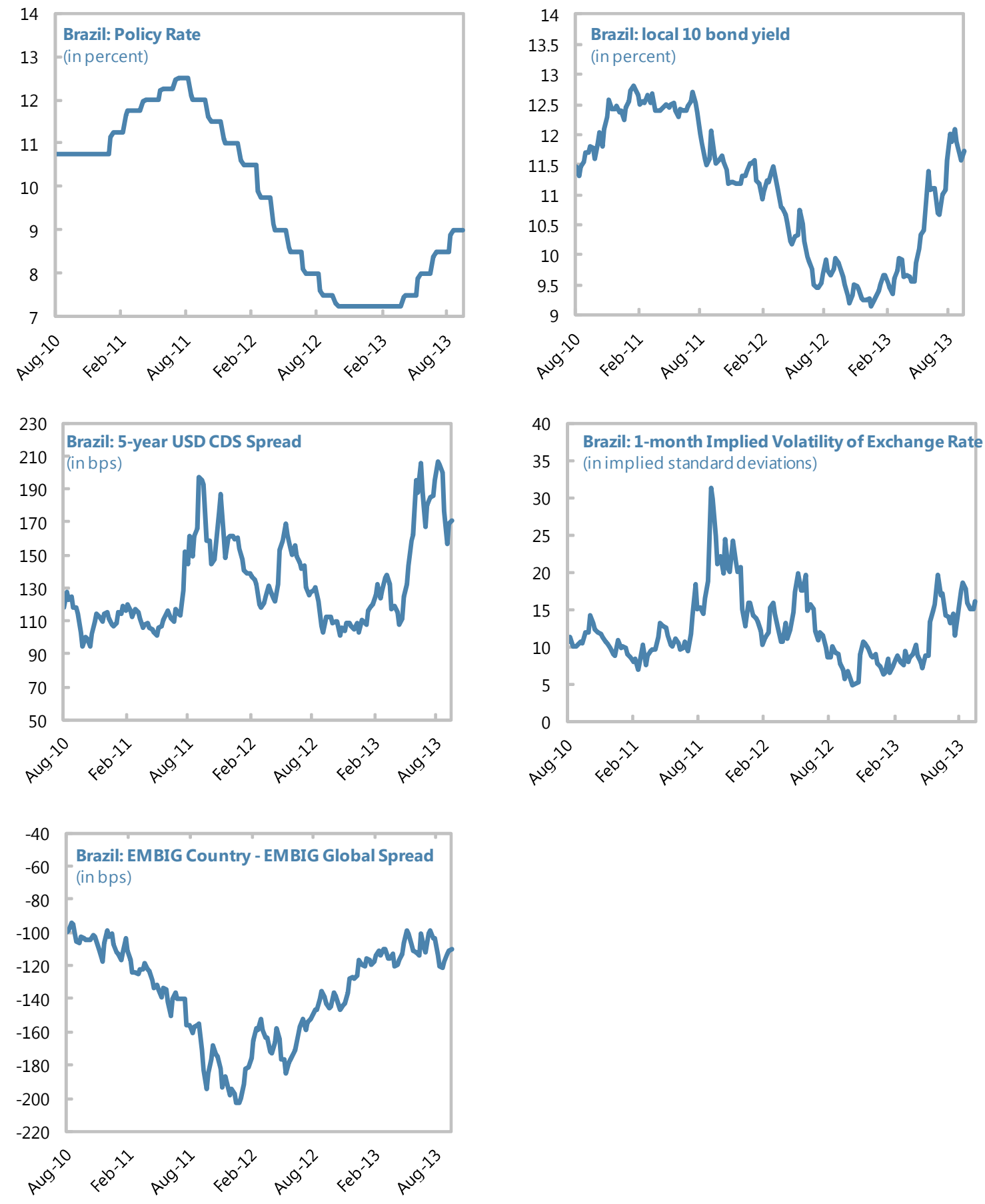

Source: Bloomberg, Reuters Datastream and Staff Estimates 
Figure A2. Mexico: Domestic Time Series
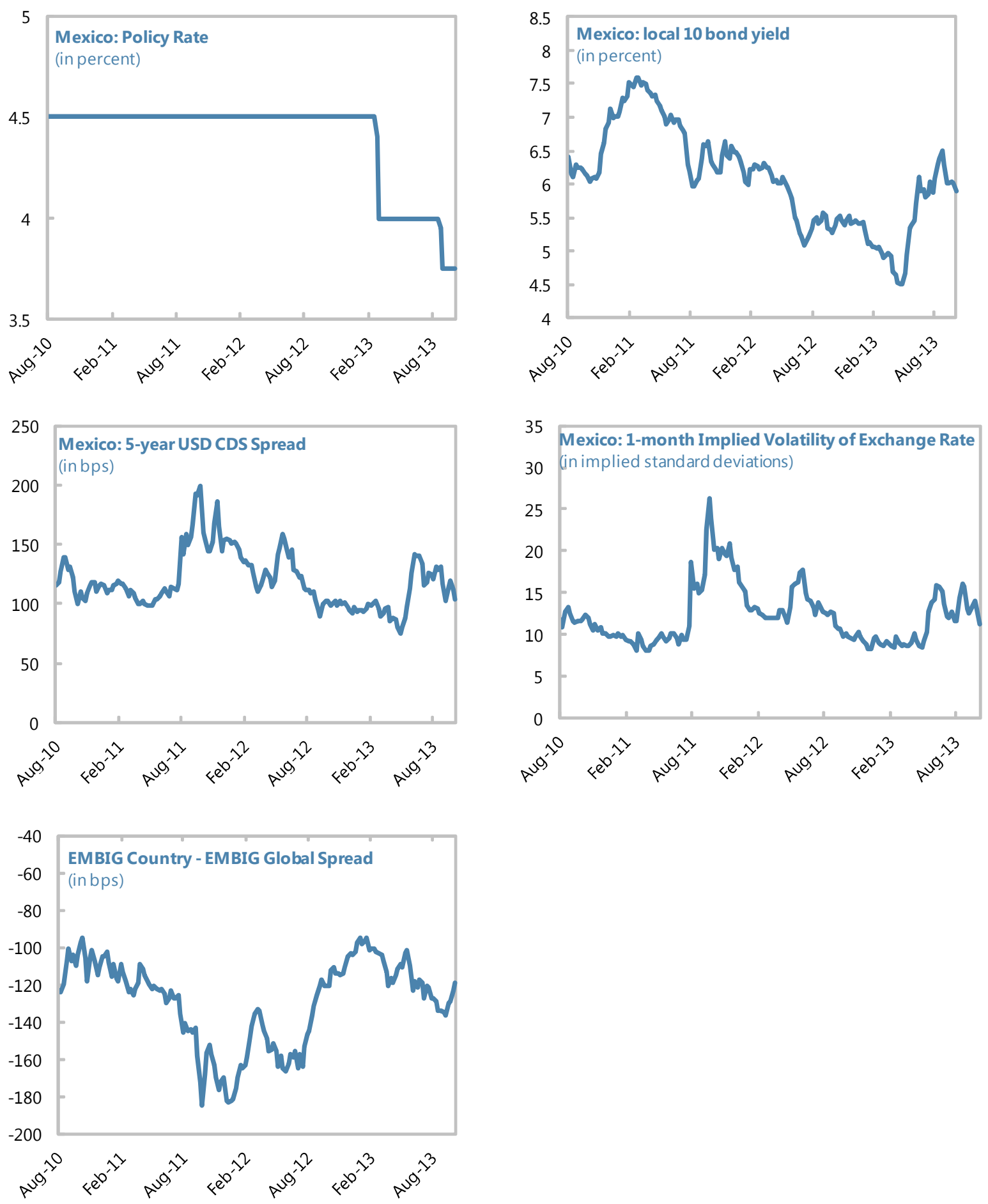

Source: Bloomberg 
Figure A3. Global Time Series
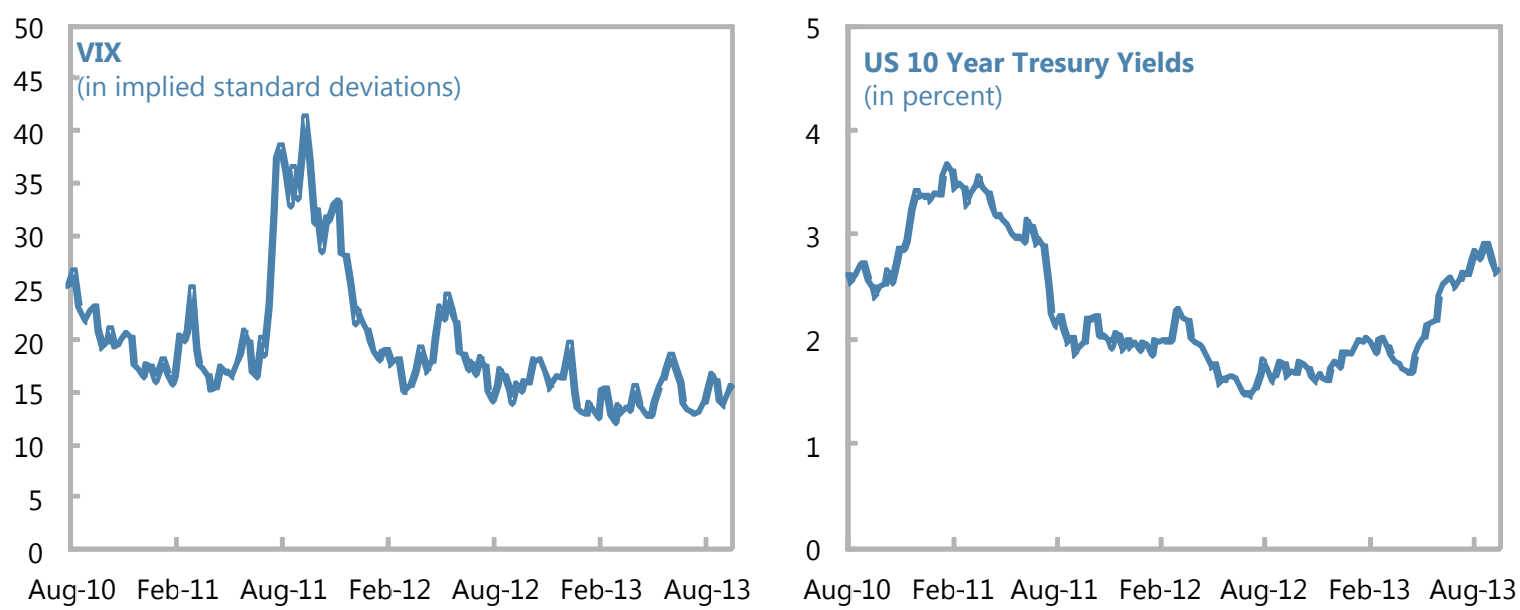

Source: Bloomberg 


\section{APPENDiX IV. IMPULSE RESPONSE FunCTIONS}

Figure A1. Brazil Impulse Response Functions 1/
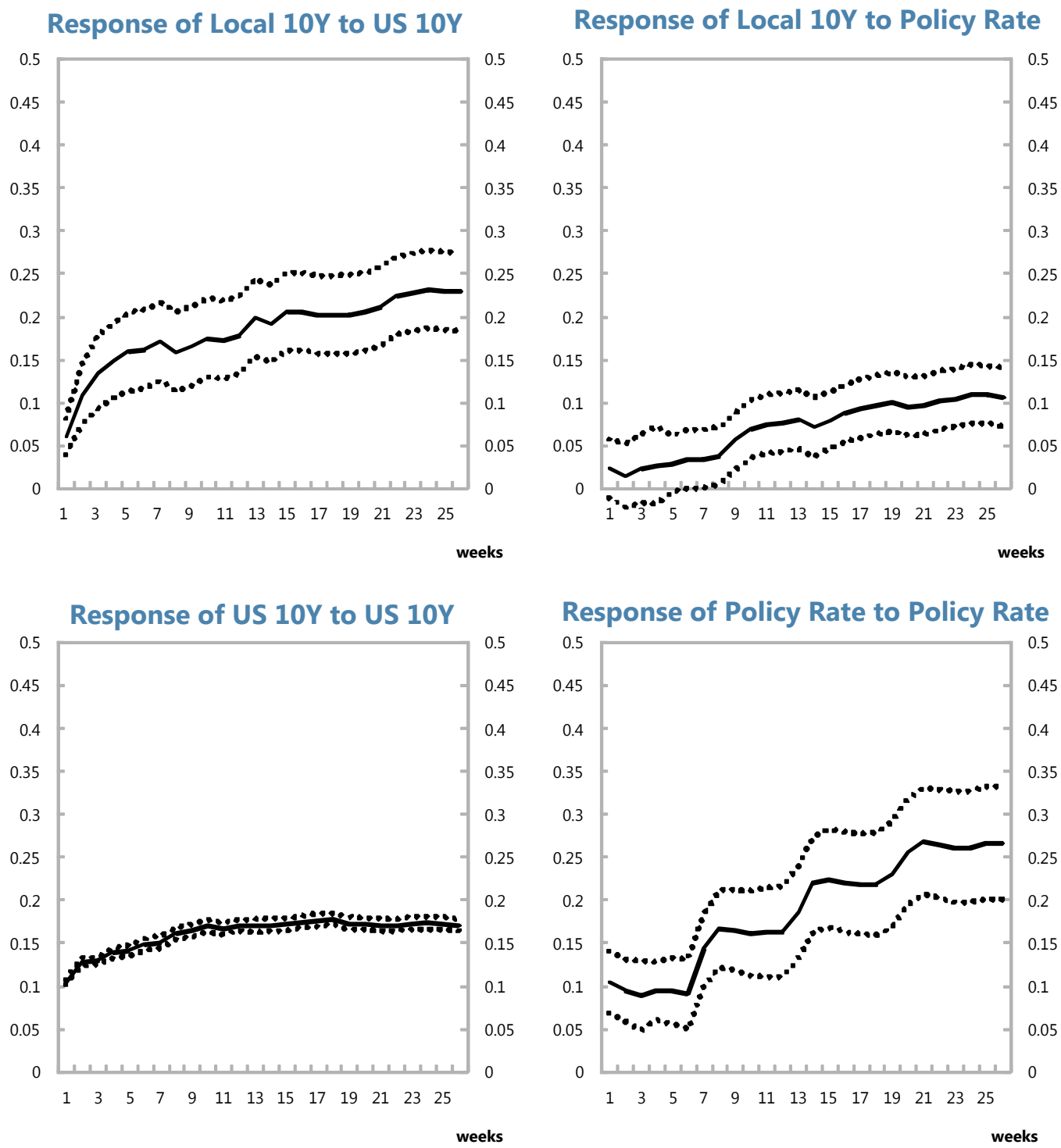

Source: IMF staff estimates.

$1 /$ Range represents $95 \%$ confidence interval. 
Figure A2. Mexico Impulse Response Functions 1/
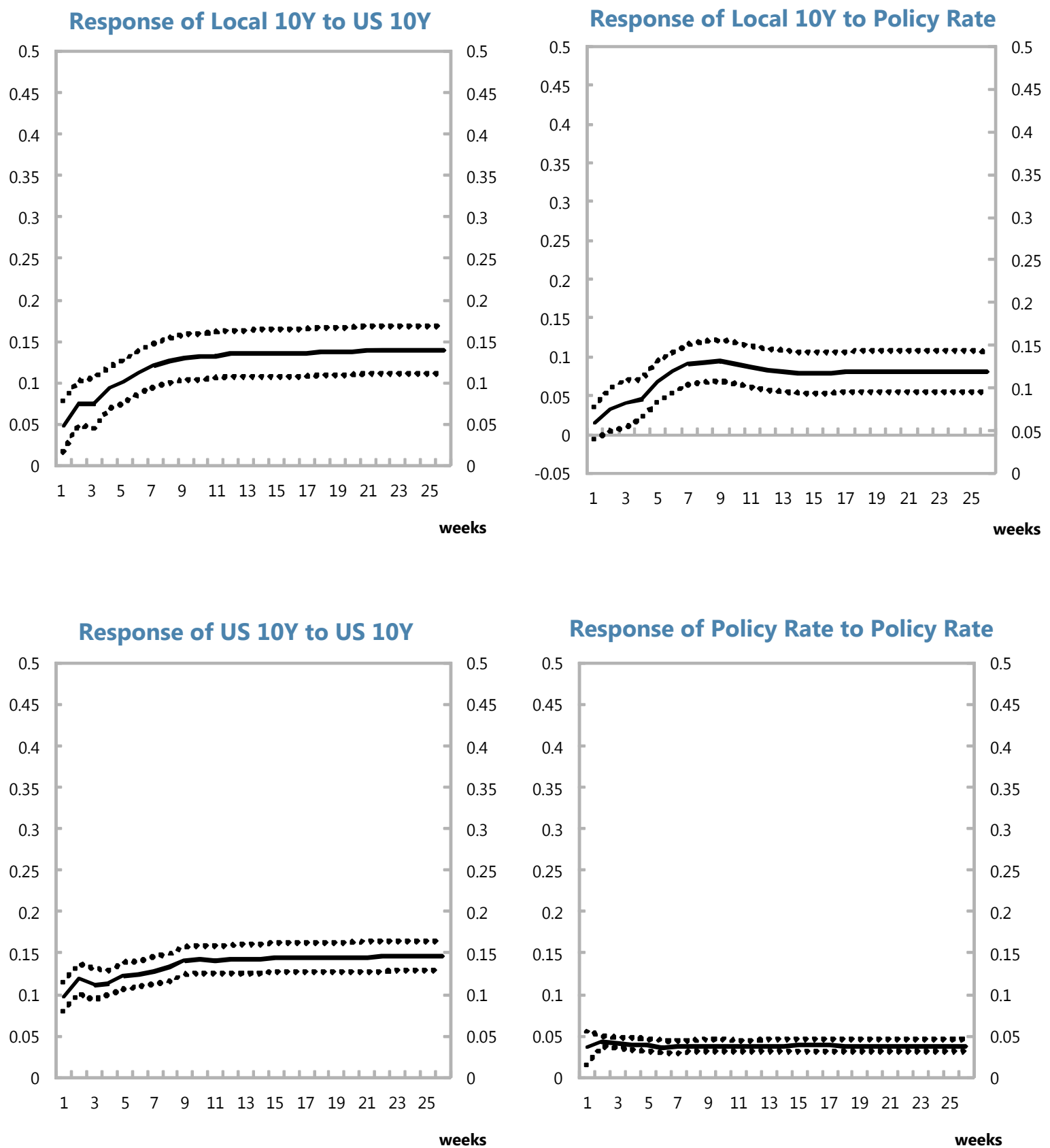

Response of Policy Rate to Policy Rate

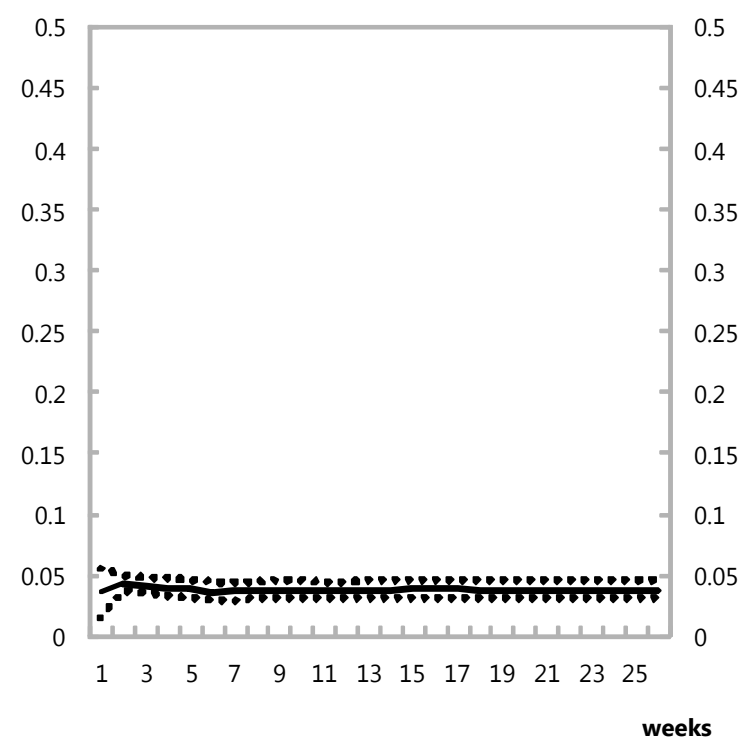

Source: IMF staff estimates.

1 / Range represents $95 \%$ confidence interval. 
Figure A3. Different Policy Rate Responses for Brazil and Mexico 1/

Response of Brazilian Policy

Rate to US $10 Y$

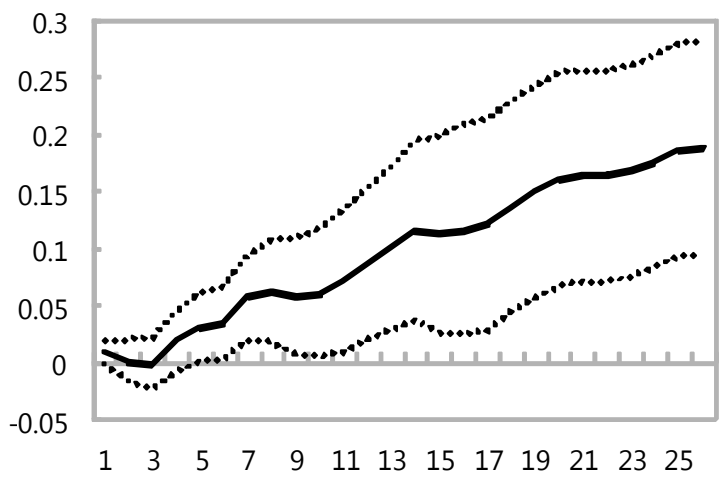

Response of Mexican Policy Rate to US $10 Y$

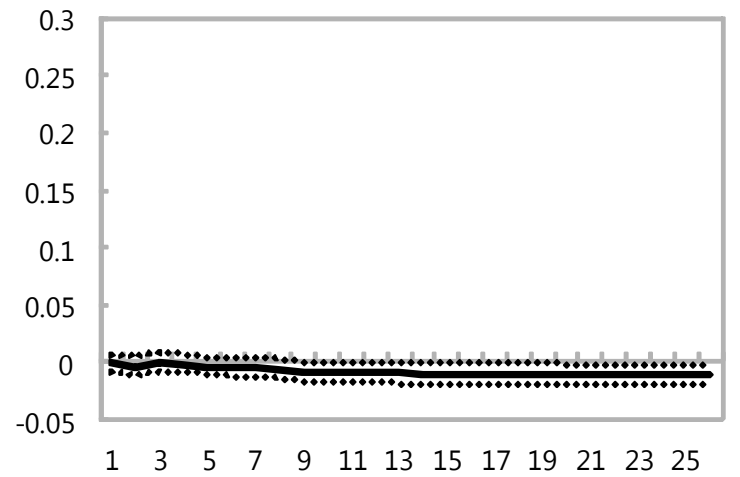

Source: IMF staff estimates.

1 / Range represents $95 \%$ confidence interval. 


\section{REFERENCES}

Anderson, P., Silva, A., Velandia-Rubiano A., 2010, "Sovereign Public Debt Management in Emerging Market Economies: Has This Time Been Different?", World Bank Policy Research Working Paper No. 5399 (Washington: World Bank).

Anderson, P., Silva, A., Velandia-Rubiano A., 2013, "Sovereign Debt Management in Crisis in ECA: A Toolkit for Policy Makers,” World Bank Report No. 4934 (Washington: World Bank).

Cortés Espada, J. F., and M. Ramos-Francia, 2008, "A Macroeconomic Model of the Term Structure of Interest rates in Mexico," Working Papers Banco de Mexico, 2008-10.

Da Silva, G. B., G. P. de Deus, G. M. N. Fleury, L. G. Leite, O. C. de Souza Lima, and T. de Oliveira Mota, 2015, "American Monetary Policy Normalization and Its Impacts on the Brazilian Yield Curve,” mimeo, Brazilian National Treasury.

Ebeke, C., and Y. Lu, 2014, "Emerging Market Local Currency Bond Yields and Foreign Holdings in the Post-Lehman Period - a Fortune or Misfortune?", IMF Working Paper No. 14/29 (Washington: International Monetary Fund).

Edwards, S., 2010, "The International Transmission of Interest Rate Shocks: The Federal Reserve and Emerging Markets in Latin America and Asia," Journal of International Money and Finance, Vol. 29, pp. 685-703.

Eichengreen, B., and A. Mody, 1998, "What Explains the Changing Spreads on Emerging Market Debt?,” NBER Working Paper No. 6408 (Cambridge, Massachusetts: National Bureau of Economic Research).

Engle, R. F., and C. W. J. Granger, 1987, "Co-Integration and Error Correction: Representation, Estimation, and Testing," Econometrica, Vol. 55 (2), pp. 251-76.

Fratzscher, M., M. Lo Duca, and R. Straub, 2013, "On the International Spillovers of U.S. Quantitative Easing,” ECB Working Paper No. 1557.

Granger, C. W. J., 1981, "Some Properties of Time Series Data and Their Use in Econometric Model Specification,” Journal of Econometrics, Vol. 16, pp. 121-30.

Hall, A.D., H. M. Anderson, and C. W. J. Granger, 1992, "A Cointegration Analysis of Treasury Bill Yields," Review of Economics and Statistics, Vol. 74, pp. 116-26.

Hjalmarsson, E., and P. Osterholm, 2007, "A Residual-Based Cointegration Test for Near Unit Root Variables," Federal Reserve Board International Finance Discussion Paper No. 907.

Howe, H., and C. Pigott, 1992, "Determinants of Long-term Interest Rates: An Empirical Study of Several Industrial Countries," Federal Reverse Bank of New York Quarterly Review, Winter, pp. 12-28. 
International Monetary Fund, 2014, "How do Changes in the Investor Base and Financial Deepening Affect Emerging Market Economies?”, Global Financial Stability Report, Chapter 2, April.

Jaramillo, L., and A. Weber, 2013, "Global Spillovers into Domestic Bond Markets in Emerging Market Economies," IMF Working Paper 13/264 (Washington: International Monetary Fund).

Johansen, S., 1991, "Estimation and Hypothesis Testing of Cointegration Vectors in Gaussian Vector Autoregressive Models," Econometrica, Vol. 59 (6), pp. 1551-80.

Johansen, S., and K. Juselius, 1992, "Testing Structural Hypotheses in a Multivariate Cointegration Analysis of the PPP and the UIP for U.K.," Journal of Econometrics, Vol. 53, pp. 211-44.

Leon, M.S., 2014, "International Capital Flows and Yields of Public Debt Bonds," Central Bank of Brazil Working Paper No. 345.

Lütkepohl, H., and H.-E. Reimers, 1992, "Granger-Causality in Cointegrated VAR Processes: The Case of the Term Structure,” Economics Letters, Vol. 40, pp. 263-68.

Maltritz, D., 2012, "Determinants of Sovereign Yield Spreads in the Eurozone: A Bayesian Approach," Journal of International Money and Finance, Vol. 31, pp. 657-72.

Matheson, T., 2015, "Normalization of Global Financial Conditions: The Implications for Brazil,” IMF Working Paper No. 15/194 (Washington: International Monetary Fund).

Mishra, P., K. Moriyama, P. N'Diaye, and L. Nguyen, 2014, “Impact of Fed Tapering Announcements on Emerging Markets," IMF Working Paper No. 14/109 (Washington: International Monetary Fund).

Moore, J., S. Nam, M. Suh, and A. Tepper, 2013, "Estimating the Impacts of U.S. LSAPs on Emerging Market Economies' Local Currency Bond Markets," Federal Reserve Bank of New York Staff Report 595.

Morgan, P. J., 2011, “The Impact of U.S. Quantitative Easing Policy on Emerging Asia," ADBI Working Paper Series 321.

Pesaran, M. H., and Y. Shin, 1996, "Cointegration and Speed of Convergence to Equilibrium," Journal of Econometrics, Vol. 71, pp. 117-43.

Phillips, P. C. B., 1988, "Regression Theory for Near-Integrated Time Series," Econometrica, Vol. 56 (5), pp. 1021-43. 